ISSN: 2338-8021; E-ISSN: 2338-8269

\title{
DAMPAK AKTIVITAS PERTAMBANGAN EMAS TANPA IZIN TERHADAP KESEJAHTERAAN RUMAH TANGGA GURANDIL
}

The Impact of the Activities of Illegal Gold Mining for Household Welfare Gurandil

\author{
Wira Fuji Astuti ${ }^{1)}$, Ivanovich Agusta ${ }^{1)}$ dan Mahmudi Siwi ${ }^{1)}$ \\ ${ }^{1)}$ Departemen Sains Komunikasi dan Pengembangan Masyarakat, Fakultas Ekologi Manusia, \\ Institut Pertanian Bogor, Darmaga Bogor 16680, Indonesia \\ Email: wira.fujiastuti@yahoo.com; iagusta@apps.ipb.ac.id; mahmudisiwi@apps.ipb.ac.id
}

\begin{abstract}
This study aimed to analyze the relationship between the factors which is stimulated the emergence gurandil with activities undertaken by gurandil in doing illegal gold mining and its relationship with the welfare of households by using Spearman rank correlation test. This research was conducted using quantitative research approach, namely the use of instruments such as questionnaires, and qualitative data supported by in-depth interviews, participant observation and document tracking. Results of this study explain that the factors stimulates the emergence gurandil associated with the level of activity in the gold mining without permission. Factors that influence the intensity of gurandil's activity is economic factors because the low level of earned income to meet family needs. Another factor that affects the activity of gurandil is legal factors and social factors. Gurandil activity levels are categorized according to the characteristics, namely gurandil shallow, regular gurandil, and gurandil barrel. Gurandil activity in gold mining without permission is gurandil shallow highest. Based on the obtained relationship gurandil activity by household welfare level gurandil seen from the physical condition of residential buildings, the level of health, education level, income level, and the level of expenditure.
\end{abstract}

Keywords: activity gurandil, driving factors, the level of welfare

\begin{abstract}
ABSTRAK
Penelitian ini bertujuan untuk menganalisis hubungan antara faktor-faktor pendorong munculnya gurandil dengan aktivitas yang dilakukan oleh gurandil dalam melakukan penambangan emas tanpa izin dan hubungannya dengan kesejahteraan rumah tangga dengan menggunakan uji korelasi Rank Spearman. Penelitian ini dilakukan menggunakan pendekatan penelitian kuantitatif, yaitu penggunaan instrumen berupa kuesioner, dan didukung data kualitatif dengan metode wawancara mendalam, observasi partisipatif, dan penelusuran dokumen. Hasil penelitian ini memaparkan bahwa faktor pendorong munculnya gurandil berhubungan dengan tingkat aktivitas gurandil dalam melakukan penambangan emas tanpa izin. Faktor yang sangat mempengaruhi tingginya aktivitas gurandil adalah faktor ekonomi karena rendahnya tingkat pendapatan yang diperoleh untuk memenuhi kebutuhan keluarga. Faktor lain yang mempengaruhi aktivitas gurandil adalah faktor hukum dan faktor sosial. Tingkat aktivitas gurandil dikategorikan sesuai dengan karakteristik gurandil yaitu gurandil cetek, gurandil biasa, dan gurandil tong. Aktivitas gurandil dalam melakukan penambangan emas tanpa izin paling tinggi adalah gurandil cetek. Berdasarkan aktivitas gurandil tersebut diperoleh hubungan dengan tingkat kesejahteraan rumah tangga gurandil yang dilihat dari kondisi fisik bangunan tempat tinggal, tingkat kesehatan, tingkat pendidikan, tingkat pendapatan, dan tingkat pengeluaran.
\end{abstract}

Kata kunci: aktivitas gurandil, faktor-faktor pendorong, tingkat kesejahteraan

\section{PENDAHULUAN}

Sebagai salah satu sektor industri dalam tatanan ekonomi global, industri pertambangan memiliki posisi dominan dalam pembangunan sosial ekonomi negara maju dan berkembang.
Hadirnya sektor industri memberikan dampak positif maupun negatif bagi masyarakat. Tanpa menampik dampak positifnya, dampak negatif dalam ranah sosial, ekonomi, lingkungan, politik, dan budaya yang ditimbulkan sektor 
industri ini lebih banyak. Dampak negatif tersebut cenderung membesar di negara-negara berkembang atau di negara-negara yang menghadapi kendala ketidakefektifan sistem pemerintahan, ketiadaan regulasi (perundangan) yang memadai serta tingginya gejolak sosialpolitik (Kristanto 2004).

Pengelolaan dan penguasaan sumber daya alam telah dibangun melalui semangat UUD 1945 Pasal 33 dengan tujuan utama adalah untuk sebesar besarnya kemakmuran bagi rakyat Indonesia. Amanat UUD 1945 ini merupakan landasan pembentukan kebijakan pertambangan yakni Undang-Undang Nomor 11 Tahun 1967 tentang Pokok Pertambangan Mineral dan Batubara yang kemudian diganti dengan Undang-Undang Nomor 4 Tahun 2009 tentang Pertambangan Mineral dan Batubara. Menurut Saleng (2007), dibentuknya Undang-Undang Nomor 4 Tahun 2009 tentang Pertambangan Mineral dan Batubara merupakan konsekuensi dari lahirnya Undang-Undang Nomor 32 Tahun 2004 Tentang Pemerintahan Daerah dan Undang-Undang Nomor 33 Tahun 2004 Tentang Perimbangan Keuangan Pemerintah Pusat dan Pemerintah Daerah sebagaimana diatur dalam Peraturan Pemerintah Nomor 25 Tahun 2000 Tentang Kewenangan Pemerintah Kabupaten/ Kota dan Provinsi sebagai Daerah Otonom.

Industri tambang mineral dan migas dapat berkembang sangat pesat karena kebutuhan dan permintaan atas mineral dan energi yang terus meningkat bersamaan dengan pertumbuhan jumlah penduduk serta kesejahteraan. Namun di balik peningkatan tersebut, terdapat dua permasalahan besar yang dihadapi industri yaitu pertama cadangan sumber alam semakin menipis dan kedua resistensi masyarakat khusus nya masyarakat lokal semakin meningkat yang terungkap dari kasus konflik antaran korporasi dengan komunitas lokal, baik diakibatkan oleh praktik tambang sendiri mapun berbentuk konflik kepentingan. Oleh sebab itu, dibalik pesatnya perkembangan industri tambang dan migas, kedudukan korporasi sangat rentan terhadap tekanan utamanya dari kalangan civil society karena persepsi umum melihat praktik industri tersebut lebih banyak memberikan dampak negatif daripada positifnya terhadap lingkungan sekitar, secara fisik maupun sosial (Prayogo 2011).
Hadirnya industri pertambangan di daerah Bogor menimbulkan daya tarik tersendiri bagi pencari kerja baik dari dalam maupun dari luar daerah pertambangan, sehingga akan menimbulkan masyarakat yang majemuk. Dengan adanya masyarakat tersebut, berbagai macam budaya dan prilaku akan berpengaruh kepada kehidupan baik pada kondisi sosial maupun kondisi ekonomi. Sebelum adanya industri mata pencarian mayarakat adalah di bidang pertanian. Seiring berkembangnya industri yang masuk ke pedesaan perlahan lahan budaya bertani mulai luntur dan masyarakat lebih tertarik untuk bekerja di industri. Akan tetapi, untuk masuk ke ranah industri masyarakat juga harus bersaing satu sama lain agar terserap oleh industri. Persaingan yang ada yaitu persaingan dalam hal keterampilan (skill) dan juga pengetahuan masyarakat pada bidang pekerjaan yang menuntut kedua hal tersebut. Hal ini terjadi saat perusahaan mengambil karyawan dari luar daerah, jika ada orang lokal biasanya perusahaan hanya memposisikan mereka sebagai satpam atau pembantu saat survei lapangan. Dikarenakan kebanyakan masyarakat asli daerah tersebut masih berpendidikan rendah dan minim dalam kemampuan.

Desa Pangkal Jaya merupakan salah satu desa yang terletak di Kecamatan Nanggung, Kabupaten Bogor yang berbatasan langsung dengan PT. Antam (Persero) Tbk UBPE Pongkor. Selain di bidang pertanian, masyarakat Desa Pangkal Jaya pada umumnya bekerja sebagai penambang emas tanpa izin atau yang dikenal dengan penambang gurandil/tikus. Sebelum beroperasinya perusahaan pertambangan di daerah gunung pongkor, penambang gurandil telah ada dengan jumlah yang sangat sedikit. Akan tetapi, fenomena peti (penambang gurandil) marak sekitar tahun 1998 akibat faktor daya tarik harga emas yang mencapai angka Rp 100000 per gram, di samping karena krisis ekonomi dan pengangguran yang melonjak. Diperkirakan ada sekitar 3000 hingga 8000 gurandil yang beroperasi di Pongkor. Sekitar $70 \%$ dari jumlah ini adalah pendatang dari Cikotok, Salopa, Tasikmalaya, Sukabumi, Bogor, Rangkasbitung, Bengkulu, Kalimantan, dan Nusa Tenggara 
Timur, sementara hanya 30\% saja yang berasal dari Desa Bantar Karet dan Desa Cisarua ${ }^{1}$.

Dampak yang yang diakibatkan oleh kegiatan tersebut diperkirakan lebih besar dibandingkan dengan perusahaan-perusahaan besar di bidang pertambangan, karena kegiatan penambangan liar dilakukan dengan menggunakan peralatan tradisional yang menyebabkan korban jiwa pada saat melakukan proses penambangan. Dari uraian diatas, maka perlu dikaji sejauhmana dampak aktivitas pertambangan emas tanpa izin terhadap tingkat kesejahteraan masyarakat gurandil?

Berdirinya perusahaan pertambangan dapat memberikan dampak positif maupun negatif terhadap sosial dan ekonomi masyarakat sekitar dan nantinya akan menghadirkan sebuah kegiatan pertambangan yang dilakukan oleh masyarakat. Kegiatan pertambangan tersebut ada yang memiliki izin dan tidak memiliki izin. Namun, sebagian besar masyarakat dalam melakukan kegiatan pertambangan tidak memiliki ijin dari pihak atau instansi manapun yang terkait. Menurut beberapa literatur dengan pandangan-pandangan yang berbeda, keberadaan perusahaan memberikan dampak yang positif, seperti yang dikemukakan Ismono (2010) menyatakan keberadaan perusahaan pertambangan belum tentu memberikan dampak yang positif terhadap masyarakat. Selain itu kegiatan penambangan tanpa izin pada suatu wilayah dapat memberikan dampak yang signifikan terhadap kondisi sosial-ekonomi masyarakat. Munculnya para penambang liar atau tanpa izin disebabkan oleh adanya berbagai faktor pendorong seperti faktor sosial, faktor ekonomi, faktor hukum dan faktor-faktor lainnya. Oleh karena itu, menjadi penting bagi peneliti untuk mengkaji sejauhmana faktor pendorong munculnya gurandil berhubungan dengan tingkat aktivitas gurandil untuk melakukan pertambangan tanpa izin?

Masyarakat yang tidak terserap oleh perusahaan pertambangan besar memilih bekerja sebagai penambang liar. Pertambangan emas tanpa izin ini bagi sebagian masyarakat menjadi tumpuan hidup, karena dapat menghasilkan pendapatan

\footnotetext{
1 Artikel menelusuri jejak gurandil di tambang emas pongkor 2011 diunduh dari http://fatullah tambangemas.blogspot.com/2011/03/menyusuri-jejakgurandil-di-tambang.html
}

yang lebih tinggi dibandingkan pada sektor pertanian. Akan tetapi pekerjaan tersebut belum tentu menjadikan hidup masyarakat sejahtera. Taraf hidup atau tingkat kesejahteraan masyarakat adalah perubahan kondisi ekonomi masyarakat yang diukur dengan tingkat pendidikan, bentuk bangunan rumah, dan kesanggupan untuk memenuhi kebutuhan primer, sekunder maupun tersier. Berdasarkan tingkat pendidikan, Paryono (2005) menyatakan bahwa semenjak beroperasinya kegiatan pertambangan, pendapatan masyarakat dari sektor pertanian lebih rendah dibandingkan dengan sektor non pertanian. Desa Pangkal Jaya merupakan salah satu desa yang berbatasan langsung dengan daerah pertambangan emas. Akan tetapi dalam kegiatannya, masyarakat lokal belum begitu terlibat. Oleh karena itu, menjadi penting bagi peneliti untuk mengkaji sejauhmana aktivitas sebagai penambang tanpa izin berhubungan dengan tingkat kesejahteraan rumah tangga gurandil?

Tujuan penelitian secara umum adalah untuk menganalisis sejauhmana dampak kegiatan pertambangan tanpa izin terhadap tingkat kesejahteraan masyarakat gurandil di Desa Pangkal Jaya, Kecamatan Nanggung, Kabupaten Bogor. Kemudian tujuan khususnya ialah menjawab pertanyaan permaasalahan, yakni:

1. Menganalisis hubungan antara faktor pendorong munculnya gurandil berhubungan dan tingkat aktivitas gurandil untuk melakukan pertambangan tanpa izin.

2. Menganalisis hubungan antara aktivitas sebagai penambang tanpa izin (gurandil) dan tingkat kesejahteraan rumah tangga gurandil

\section{PENDEKATAN TEORITIS \\ Pengertian Pertambangan}

Berdasarkan Peraturan Menteri Energi dan Sumberdaya Mineral Republik Indonesia Nomor 24 Tahun 2012, pertambangan adalah rangkaian kegiatan dalam rangka upaya pencarian, penambangan (penggalian), pengolahan, pemanfaatan dan penjualan bahan galian (mineral, batubara, panas bumi, migas). Hasil penelitian Risal et al (2013) menyatakan bahwa terdapat sejumlah unsur yang sudah pasti melekat pada pertambangan, yakni adanya tindakan penghancuran/pengrusakan, kebohongan, mitos, dan keuntungan untuk segelintir orang 
tertentu (orang kaya). Objek dari usaha pertambangan adalah sumber daya alam yang tak terbaharukan (non-renewable), dimana dalam pengelolaan dan pemanfaatannya dibutuhkan pendekatan manajemen ruangan yang ditangani secara holistik dan integratif dengan memperhatikan empat aspek pokok yaitu, aspek pertumbuhan (growth), aspek pemerataan (equity), aspek lingkungan (environment), dan aspek konservasi (conservation).

Manan dan Saleng (2004) dalam Siregar (2009) juga menyatakan bagaimana peran kegiatan pertambangan. Pertambangan memiliki peran yang strategis dan kontribusi besar terhadap pembangunan daerah. Beroperasinya kegiatan pertambangan di suatu daerah, komunitas baru akan terbentuk sebagai pusat pertumbuhan ekonomi baru di wilayah beroperasinya pertambangan. Komunitas baru tersebut akan memberikan pengaruh terhadap perekonomian daerah setempat, sebab masyarakat pencari kerja dan pelaku ekonomi akan tertarik ke wilayah pertumbuhan yang baru dan menyebabkan jasajasa lainnya akan tumbuh, baik jasa yang terkait langsung maupun tidak langsung dengan kegiatan pertambangan.

\section{Pertambangan Emas Tanpa Izin (Peti)}

Kegiatan Peti adalah usaha pertambangan yang dilakukan oleh perorangan, sekelompok orang atau perusahaan/yayasan berbadan hukum yang dalam operasinya tidak memiliki izin dari instansi pemerintah pusat atau daerah sesuai dengan perundang-undangan yang berlaku. Menurut Ngadiran, Santoso dan Purwoko (2002) persolan-persoalan kegiatan pertambangan emas tanpa izin diantaranya:

a. Keselamatan kerja kurang terjamin karena para penambang dalam pengolahan bijih emas menggunakan bahan kimia beracun seperti sianida dan merkuri

b. Modal kerja ditanggung oleh seorang pemilik lubang atau pemilik mesin. Cara patungan diupayakan diantara penambang sekalipun jumlahnya sangat terbatas. Apabila modal tetap saja belum mencukupi, para penambang sering sekali terpaksa hutang karena tidak ada bank yang mau memberikan kredit

c. Para penambang bekerja dengan teknik yang sederhana yang dipelajari secara tradisional dan turun-temurun, sehingga tidak terjadi inovasi.

Sumantri dan Herman (2007) dalam Wibisono (2008) menyatakan bahwa faktor pendorong kehadiran Peti dapat dikelompokkan menjadi:

1. Faktor sosial, kegiatan yang sudah menjadi pekerjaan turunan karena dilakukan secara turun-temurun oleh masyarakat setempat; terdapatnya hubungan yang kurang harmonis antara pertambangan resmi atau berizin dengan masyarakat setempat; dan terjadinya penafsiran keliru tentang reformasi yang diartikan sebagai kebebasan tanpa batas.

2. Faktor hukum, yaitu ketidaktahuan masyarakat terhadap peraturan perundangundangan yang berlaku di bidang pertambangan; kelemahan peraturan perundang-undangan di bidang pertambangan, yang diantara lain tercermin dalam kekurangberpihakan kepada kepentingan masyarakat luas dan tidak adanya teguran terhadap pertambangan resmi atau berizin yang tidak memanfaatkan wilayah usahanya (lahan tidur); serta terjadinya kelemahan dalam penegakan hukum dan pengawasan.

3. Faktor ekonomi disebabkan oleh keterbatasan lapangan kerja dan kesempatan berusaha yang sesuai dengan tingkat keahlian atau keterampilan masyarakat bawah; kemiskinan dalam berbagai hal, yakni miskin secara ekonomi, pengetahuan, dan keterampilan; keberadaan pihak ketiga yang memanfaatkan kemiskinan untuk tujuan tertentu, yaitu penyandang dana (cukong), beking (oknum aparat) dan LSM; krisis ekonomi berkepanjangan yang melahirkan pengangguran terutama dari kalangan masyarakat bawah.

\section{Dampak Aktivitas Pertambangan}

Kristanto (2004) menjelaskan dampak adalah setiap perubahan yang terjadi dalam lingkungan akibat adanya aktivitas manusia. Disini tidak disebutkan karena adanya proyek, karena proyek sering diartikan sebagai bangunan fisik saja, sedangkan banyak proyek yang bangunan fisiknya relatif kecil atau tidak ada, tetapi dampaknya besar. Jadi yang menjadi objek pembahasan bukan saja dampak proyek terhadap lingkungan, melainkan juga dampak lingkungan terhadap proyek. Dampak penambangan 
merupakan perubahan lingkungan yang disebabkan oleh kegiatan usaha eksploitasi baik perubahan sosial, ekonomi, budaya, kesehatan maupun lingkungan alam.

Kegiatan Peti memberikan dampak baik itu dampak positif maupun dampak negatif terhadap aspek ekologi dan sosial-ekonomi kepada masyarakat lokal. Kegiatan Peti pada umumnya tidak ramah lingkungan, karena hanya mengejar kepentingan dalam waktu singkat seperti halnya bagaimana untuk mendapatkan uang. Hal ini disebabkan oleh minimnya kesadaran untuk tetap melestarikan lingkungan. Tidak hanya kerusakan lingkungan yang ditimbukan oleh kegiatan Peti tetapi juga menelan korban jiwa yang jumlahnya lebih besar dibandingkan perusahaan pertambangan. Berdasarkan aspek sosial ekonomi, kegiatan Peti diharapkan dapat memberikan manfaat tidak hanya terhadap pembangunan tetapi juga terhadap masyarakat lokal yang berada di sekitar lokasi penambangan. Dalam skala makro, Peti dilihat sebagai bahaya dan ancaman bagi investasi pertambangan di Indonesia. Namun, dalam skala mikro penambangan emas dapat digolongkan sebagai salah satu gerakan "ekonomi kreatif" yang memenuhi kebutuhan hidup rakyat kecil. Mereka berusaha menggali dan menemukan butiran emas demi perbaikan hidup ekonomi para penambang. Setiap hari mereka dapat memenuhi kebutuhan hidup seperti berbelanja, membayar uang sekolah anak, berobat, membeli kendaraan bermotor dan meniti masa depan yang lebih baik (Willybrodus, dan Chang (2012).

\section{Dampak Aspek Sosial-Ekonomi}

Dampak sosial ekonomi merupakan dampak aktivitas pertambangan pada aspek sosial ekonomi yang dapat bersifat positif dan negatif. Budimanta (2007) menunjukkan bahwa aktivitas penambangan di daerah Bangka Belitung memberikan berbagai dampak positif dan negatif pada kehidupan warga. Dampak positif diantaranya adalah meningkatnya penghasilan devisa bagi negara, terciptanya lapangan pekerjaan. Selain itu, adanya perbaikan infrastruktur seperti akses jalan ke Penagan dari Pangkal Pinang menjadi semakin mudah dan kondisi jalanan semakin baik. Waktu tempuh menjadi semakin efisien dibandingkan sebelumnya yang membutuhkan waktu hingga dua hari bagi para pejalan kaki. Pada aspek ekonomi, pendapatan yang diperoleh warga menjadi semakin meningkat. Hal ini terlihat dari adanya kemampuan warga untuk mendirikan rumah permanen yang terbuat dari bahan bata dan semen, dibandingkan kondisi sebelumnya yang hanya terbuat dari kayu penyangga.

Masuknya sebuah industri dalam suatu wilayah dapat berpengaruh terhadap pergerakan penduduk, seperti halnya dapat memicu terjadi migrasi penduduk. Dijelaskan oleh Rusli (1995) migrasi adalah suatu bentuk gerak penduduk geografis, spasial atau teritorial antara unit-unit geografis yang melibatkan perubahan tempat tinggal yaitu dari tempat asal ke tempat tujuan. Seseorang melakukan migrasi apabila ia melakukan pindah tempat tinggal secara permanen atau relatif permanen dengan menempuh jarak minimal tertentu atau pindah dari satu geografis ke geografis lainya. Banyak faktor melatarbelakangi seseorang melakukan migrasi seperti halnya adalah dalam memperoleh pekerjaan.

\section{Kesejahteraan}

Kesejahteraan sosial pada intinya mencakup tiga konsepsi yaitu: Pertama kondisi kehidupan atau keadaan sejahtera yakni terpenuhinya kebutuhan-kebutuhan jasmaniah, rohaniah, dan sosial. Kedua institusi, arena atau bidang kegiatan yang melibatkan lembaga kesejahteraan sosial dan berbagai profesi kemanusiaan yang menyelenggarakan usaha kesejahteraan sosial dan pelayanan sosial. Dan ketiga aktivitas, yakni kegiatan-kegiatan atau usaha yang terorganisir untuk mencapai kondisi sejahtera (Suharto 2005).

Konsep kesejahteraan dikemukakan oleh BPS (2005) bahwa ada tujuh indikator yang digunakan untuk mengetahui tingkat kesejahteraan antara lain: pendapatan, konsumsi atau pengeluatan keluarga, fasilitas tempat tinggal, kesehatan keluarga, kemudahan mendapatkan pelayanan kesehatan, kemudahan mendapatkan fasilitas transportasi, dan kemudahan mendapat akses pendidikan. Berdasarkan pengertian dari para ahli di atas, dapat digambarkan bahwa pendapatan, kesehatan, pendidikan, akses transportasi, kepentingan dan kebutuhan keluarga serta masyarakat merupakan tolak ukur atau indikator untuk mengukur dan menentukan tingkat kesejahteraan masyarakat.

\section{Kerangka Pemikiran}


Berdirinya perusahaan pertambangan emas akan memberikan pengaruh, baik itu positif maupun negatif. Terlihat dari keberadaan perusahaan pertambangan tersebut dapat memberikan kontribusi yang positif terhadap tingkat pendapatan daerah. Perusahaan pertambangan besar atau perusahaan legal akan mendorong munculnya para penambang liar atau penambang tanpa izin yang diakibatkan tidak terserapnya tenaga kerja dari kalangan pribumi. Berbagai faktor pendorong seperti faktor sosial, faktor hukum, dan faktor ekonomi. Faktor-faktor tersebut akan mempengaruhi tingkat aktivitas masyarakat untuk melakukan pertambangan tanpa izin. Tingkat aktivitas dapat dilihat dari lama bekerja, frekuensi bekerja, tingkat modal kerja, dan tingkat keselamatan kerja. Dari indikator terebut dapat dilihat sejauh mana aktivitas masyarakat penambangan liar dengan menggunakan teknik-teknik sederhana dan secara tradisional. Dalam kerangka analisis juga dijelaskan pembukaan pertambangan mempengaruhi masyarakat untuk menjadi penambang liar yang juga memberikan dampak positif dan negatif baik dalam bidang sosial maupun ekonomi. Hal ini akhirnya sangat mempengaruhi kesejahteraan masyarakat terutama masyarakat lokal (lihat Gambar 1).

\section{Hipotesis}

Berdasarkan kerangka pemikiran di atas, maka hipotesis penelitian disajikan sebagai berikut:

1.Terdapat hubungan antara faktor pendorong munculnya gurandil dengan dengan tingkat aktivitas gurandil.

\begin{tabular}{|c|c|c|}
\hline $\begin{array}{l}\underline{\mathbf{X}}_{\mathbf{1}} \underline{\text { Tingkat }} \\
\underline{\mathbf{F} \text { aktor }} \\
\underline{\text { Pendorong }} \\
\mathrm{x}_{1.1} \text { Tingkat } \\
\text { faktor sosial } \\
\mathrm{x}_{1.2} \text { Tingkat } \\
\text { faktor hukum } \\
\mathrm{x}_{1.3} \text { Tingkat } \\
\text { faktor } \\
\text { ekonomi }\end{array}$ & $\begin{array}{l}\text { X2 Tingkat } \\
\text { Aktivitas } \\
\text { Pertambangan } \\
\text { Tanpa Izin } \\
\text { X2.1 Lama } \\
\text { bekerja } \\
\text { X2.2 Frekuensi } \\
\text { bekerja } \\
\text { X2.3 Tingkat } \\
\text { modal kerja } \\
\text { X2.4 Tingkat } \\
\text { keselamatan } \\
\text { kerja } \\
\text { X2.5 Tingkat } \\
\text { migrasi }\end{array}$ & $\begin{array}{l}\text { Y Tingkat } \\
\text { Kesejahteraan } \\
\text { Y1Tingkat perubahan } \\
\text { luas lantai } \\
\text { Y2Tingkat perubahan } \\
\text { jenis lantai } \\
\text { Y3Tingkat perubahan } \\
\text { sumber penerangan } \\
\text { rumah tangga } \\
\text { Y4Tingkat perubahan } \\
\text { fasilitas MCK } \\
\text { Y5Tingkat perubahan } \\
\text { fasilitas transportasi } \\
\text { Y }_{6} \text { Tingkat kesehatan } \\
\text { Y7 Tingkat pendapatan } \\
\text { Y8 Tingkat pengeluaran } \\
\text { Y9 Tingkat pendidikan }\end{array}$ \\
\hline
\end{tabular}

Gambar 1 Kerangka Pemikiran
2.Terdapat hubungan antara tingkat aktivitas gurandil dengan tingkat kesejahteraan rumah tangga gurandil.

Dari hipotesis penelitian di atas, dapat diajukan hipotesis uji sebagai berikut:

1.Semakin tinggi faktor pendorong munculnya gurandil, maka semakin tinggi tingkat aktivitas gurandil untuk melakukan pertambangan tanpa izin

2.Semakin tinggi tingkat aktivitas gurandil melakukan pertambangan tanpa izin, maka semakin tinggi tingkat kesejahteraan rumah tangga gurandil.

\section{PENDEKATAN LAPANGAN}

Penelitian ini menggunakan pendekatan kuantitatif didukung oleh data kualitatif. Pendekatan kuantitatif dengan menggunakan metode sensus rumah tangga gurandil, kuesioner digunakan sebagai instrumen untuk mengumpulkan informasi dari responden. Penelitian kuantitatif ini bersifat explanatory research yang menjelaskan hubungan-hubungan kausal antara variebel melalui pengujian hipotesa (Singarimbun dan Effendi 2006). Pendekatan kuantitatif diharapkan dapat menjawab bagaimana dampak yang ditimbulkan oleh faktor pendorong dan aktivitas pertambangan emas tanpa izin terhadap kesejahteraan rumah tangga gurandil yang dapat dilihat dari tingkat pendidikan, peluang kerja, tingkat pendapatan, tingkat pengeluaran dan jenis pemukiman. 
Data kualitatif digunakan dengan melakukan wawancara mendalam kepada informan menggunakan panduan pertanyaan untuk memahami secara mendalam dan rinci mengenai suatu peristiwa, serta dapat menggali berbagai realitas, proses sosial, dan makna yang berkembang dari orang-orang yang menjadi subjek penelitian. Informasi yang diperoleh melalui pendekatan kualitatif ini digunakan sebagai interpretasi terhadap data yang didapatkan dari pendekatan kuantitatif.

Penelitian mengenai dampak aktivitas pertambangan emas tanpa ijin terhadap kesejahteraan rumah tangga gurandil dilakukan di Desa Pangkal Jaya, Kecamatan Nanggung, Kabupaten Bogor, Provinsi Jawa Barat. Penentuan lokasi penelitian dilakukan secara sengaja (purposive) karena Desa Pangkal Jaya merupakan salah satu desa yang berbatasan langsung dengan lokasi pertambangan yaitu PT. Antam (Persero) Tbk Pongkor dan sebagian besar masyarakat (85\%) bekerja sebagai penambang tanpa izin atau yang lebih dikenal dengan gurandil serta desa tersebut termasuk ke dalam kategori Ring 1. Proses penelitian dimulai pada bulan Desember 2014 hingga Januari 2015.

Populasi penelitian ini adalah keseluruhan masyarakat yang bekerja sebagai gurandil yang ada di Desa Pangkal Jaya dengan unit analisis yaitu rumah tangga. Penelitian ini menggunakan sensus terhadap seluruh rumah tangga gurandil . Selanjutnya ditentukan sampel penelitian sebanyak 32 orang responden. Pengambilan sample atau responden dalam penelitian ini menggunakan teknik simple random sampling. Informan adalah orang yang dapat menjelaskan dan memberikan keterangan atau gambaran mengenai dirinya sendiri, keluarga, pihak lain dan lingkunganya. Informan juga dikatakan sebagai pihak yang dapat mendukung keberlangsungan informasi penelitian secara lancar. Adapun informan yang diambil adalah instansi terkait dalam penelitian ini seperti perangkat Desa Pangkal Jaya, tokoh masyarakat seperti ketua RT, ketua RW, dan gurandi serta masyarakat. Banyaknya informan tidak dibatasi, akan tetapi informan tersebut sudah dapat memberikan informasi yang relevan dan dapat membantu peneliti dalam menjawab perumusan masalah dalam penelitian ini.
Tabel 1 Pemilihan Informan

\begin{tabular}{ll}
\hline Kerangka Berfikir & Informan \\
\hline Faktor-faktor & - Masyarakat \\
pendorong & - Ketua RT \\
& - Ketua RW \\
& - Kepala Desa \\
\hline Aktivitas gurandil & - Gurandil \\
\hline Kondisi & - Perangkat desa \\
kesejahteraan & - Ketua RT/RW \\
& - Kepala desa \\
& - Masyarakat \\
\hline
\end{tabular}

Penelitian ini menggunakan jenis data primer dan data sekunder. Data sekunder merupakan data yang diperoleh dari dokumen-dokumen tertulis baik yang berupa tulisan ilmiah ataupun dokumen resmi dari instansi terkait. Pengumpulan data dilakukan untuk mendapatkan data dan informasi yang relevan dan berguna mengenai penelitian ini.

Tabel 2 Teknik pengumpulan data dan jenis data

\begin{tabular}{|c|c|}
\hline $\begin{array}{c}\text { Teknik } \\
\text { Pengumpulan } \\
\text { Data } \\
\end{array}$ & Data yang Dikumpulkan \\
\hline Kuesioner & $\begin{array}{l}\text { 1. Karakteristik responden } \\
\text { 2. Karakteristik rumah tangga } \\
\text { 3. Aktivitas gurandil } \\
\text { 4. Faktor pendorong } \\
\text { 5. Tingkat kesejahteraan rumah } \\
\text { tangga } \\
\text { 6. Migrasi }\end{array}$ \\
\hline $\begin{array}{l}\text { Wawancara } \\
\text { mendalam }\end{array}$ & $\begin{array}{l}\text { 7. Faktor-faktor pendorong } \\
\text { 8. Aktivitas gurandil } \\
\text { 9. Tingkat kesejahteraan rumah } \\
\text { tangga } \\
\text { 10. Kebijakan tentang undang } \\
\text { undang }\end{array}$ \\
\hline $\begin{array}{l}\text { Observasi } \\
\text { lapangan dan } \\
\text { dokumentasi }\end{array}$ & $\begin{array}{l}\text { 11. Gambaran umum desa melalui } \\
\text { profil desa } \\
\text { 12. Kondisi tempat tinggal } \\
\text { 13. Sarana dan prasarana } \\
\text { 14. Cara pengolahan hasil } \\
\text { tambang }\end{array}$ \\
\hline
\end{tabular}

Data sekunder dapat diperoleh dari instansi terkait data dari kantor kepala desa dan studi literatur penelitian sebelumnya yang mendukung kebutuhan data mengenai fokus penelitian seperti profil desa, masyarakat, kondisi geografis, demografis, sosial ekonomi dan budaya serta tingkat kesejahteraan. Data primer diperoleh melalui pengamatan langsung pada lokasi penelitian. Dalam melakukan pengamatan 
secara langsung, peneliti juga melakukan wawancara mendalam kepada informan dengan mengacu pada panduan pertanyaan dan kuesioner kepada responden.

Penelitian ini mempunyai dua jenis data yang diolah dan dianalisis yaitu data kuantitaif dan data kualitatif. Data kuantitatif menggunakan aplikasi Microsoft Excel 2007 dan SPSS for windows 16.0. Pembuatan tabel frekuensi, grafik, diagram, serta tabel tabulasi silang untuk melihat data awal responden untuk masingmasing variabel secara tunggal menggunakan aplikasi Microsoft Excel 2007. Kemudian SPSS for windows 16.0 digunakan untuk membantu dalam uji statistik dengan menggunakan Rank Spearman. Uji korelasi Rank Spearman digunakan untuk mengetahui ada atau tidaknya hubungan antar dua variabel yang berskala ordinal dan tidak menentukan prasyarat data terdistribusi normal. Rank Spearman digunakan untuk uji korelasi yang menghubungkan variabel faktor-faktor pendorong, tingkat aktivitas gurandil serta adanya hubungan keduanya dengan tingkat kesejahteraan rumah tangga gurandil.

Data kualitatif dianalisis melalui tiga tahap yaitu reduksi data, penyajian data, dan verifikasi. Pertama ialah proses reduksi data dimulai dari proses pemilihan, penyederhanaan, abstraksi, hingga transformasi data hasil wawancara mendalam, observasi, dan studi dokumen. Tujuan dari reduksi data ini ialah untuk mempertajam, menggolongkan, mengarahkan, dan membuang data yang tidak perlu. Kedua ialah penyajian data yang berupa menyusun segala informasi dan data yang diperoleh menjadi serangkaian kata-kata yang mudah dibaca ke dalam sebuah laporan. Penyajian data berupa narasi, diagram, dan matriks. Verifikasi adalah langkah terakhir yang merupakan penarikan kesimpulan dari hasil yang telah diolah pada tahap reduksi. Verifikasi dilakukan dengan mendiskusikan hasil olahan data kepada responden, informan, dan dosen pembimbing.

\section{HASIL DAN PEMBAHASAN}

\section{Faktor Pendorong Munculnya Penambang Emas Tanpa Izin (Gurandil)}

\section{Karakteristik Responden}

Responden dalam penelitian ini terdapat 32 gurandil yang bekerja sebagai yang tinggal di Desa Pangkal Jaya, Kecamatan Nanggung,
Kabupaten Bogor. Gurandil yang ada di Desa Pangkal Jaya mempunyai ciri yang terdiri dari tiga karakteristik yaitu gurandil cetek (kecil), gurandil biasa, dan gurandil tong.

Kategori umur dalam penelitian ini didasarkan pada kategori umur menurut Rusli (2012). Dalam penelitian ini, umur dikelompokkan berdasarkan kategori gurandil yaitu gurandil cetek, gurandil biasa, dan gurandil tong. Berdasarkan hasil penelitian, umur responden berkisar dari 19 tahun sampai dengan 45 tahun.

Berdasarkan tingkat pendidikan sebagian besar responden tergolong rendah yaitu tidak tamat $\mathrm{SD} /$ Sederajat atau tidak sekolah. Rendahnya tingkat pendidikan responden disebabkan karena kesulitan ekonomi keluarga yang tidak mampu untuk membayar uang pendidikan. Dengan bekerja di bidang pertanian masyarakat Desa Pangkal Jaya tidak bisa mencukupi dalam pemenuhan kebutuhan keluarga. Oleh karena itu dengan adanya potensi sumber daya alam yaitu potensi penambangan emas yang ada di Gunung Pongkor menyebabkan masyarakat di Desa Pangkal Jaya beralih profesi sebagai penambang gurandil atau tikus yang akan menghasilkan uang lebih cepat dari pada di bidang pertanian.

\section{Faktor Sosial}

Faktor sosial merupakan salah satu faktor pendorong masuknya penambang gurandil/tikus ke suatu daerah yaitu Desa Pangkal Jaya yang dapat dilihat dari tingkat hubungan antar pihak baik antara masyarakat dengan masyarakat maupun masyarakat desa dengan pihak pertambangan resmi yaitu PT. Antam (Persero) Tbk UPBE Pongkor.

Berdasarkan hasil penelitian, jika dilihat dari hubungan yang terjadi antar sesama warga dalam melakukan kegiatan sehari hari tergolong baik. Adanya gotong royong, kerja bakti yang terjadi untuk kepentingan bersama sering dilakukan misalnya dalam pembuatan fasilitas umum seperti pembuatan mesjid untuk beribadah dan jalan umum. Dalam menjalin silaturrahmi, masyarakat asli/pribumi mengadakan pengajian secara rutin seminggu sekali. Pengajian tersebut diadakan secara bergeliran karena lokasi antar kampung yang ada di desa sangatlah jauh. Menurut penuturan salah satu ketua RT di Desa Pangkal Jaya, jika dilihat hubungan antar warga asli dengan pendatang tidak begitu baik karena adanya perbedaan 
seperti prinsip, kesempatan dalam mengakses layanan atau fasilitas publik, bersaing dalam mendapatkan pekerjaan. Masyarakat asli/pribumi sangat sulit untuk mendapakan pekerjaan yang memadai dan dapat memenuhi kebutuhan keluarga. Dengan masuknya masyarakat bukan pribumi menyebabkan adanya suatu kompetisi dalam hal mendapatkan pekerjaan atau bekerja salah satunya adalah bekerja sebagai gurandi/penambang emas tanpa ijin yang berlokasi di Gunung Pongkor.

Perbedaan-perbedaan tersebut mulai berubah menjadi persamaan tujuan ketika warga pendatang telah menjadi warga Desa Pangkal Jaya dengan cara menikah atau membawa keluarga untuk menetap di Desa Pangkal Jaya. Dapat di simpulkan bahwa warga asli/ pribumi tidak bisa menerima secara langsung orang asing yang masuk ke desa mereka. Berdasarkan hasil penelitian, jika dilihat hubungan yang terjalin antara masyarakat dengan pihak perusahaan PT. Antam (Persero) Tbk UPBE Pongkor tergolong kurang harmonis. Hubungan terjadi ketika perusahaan baru beroperasi dengan saat ini mulai renggang. Hubungan tersebut terlihat juga dari banyaknya masyarakat yang tidak bisa bekerja di pertambangan dan pihak pertambangan lebih membutuhkan orang-orang yang mempunyai pendidikan dan keterampilan yang lebih baik. Selain itu juga terlihat bahwa,

\footnotetext{
Masyarakat atau warga desa ini sekarang dipersulit untuk mencari nafkah untuk anak istri. Sekarang ada peraturan jika gurandil terkena razia atau terkangkap, langsung dibawa ke Cibinong tidak lagi sebatas di polsek Nanggung. Yang dahulunya bisa diselesaikan dengan cara keluarga dan musyawarah sekarang malah malah dibikin ribet neng. Belum lagi ongkosnya". (AM, 2015)
}

Dapat disimpulkan, semakin tinggi atau semakin baik hubungan yang terjadi sesama warga asli, maupun dengan warga pendatang, maka semakin tinggi tingkat tingkat kepercayaan dan semakin banyak orang yang berdatangan baik untuk bekerja maupun untuk hal lainnya. Sedangkan semakin kurang baik hubungan masyarakat dengan pihak perusahaan, maka semakin tinggi atau semakin banyak orang yang menjadi penambang tanpa izin.

\section{Faktor Hukum}

Indonesia merupakan negara yang berlandaskan pada hukum yang berlaku di setiap sektor. Sektor pertambangan merupakan salah satu sektor yang memiliki peraturan yang diatur dalam undang-undang pertambangan dan memiliki landasan hukum dalam pengoperasiannya. Hukum yang berlaku di Indonesia khususnya di sektor pertambangan telah banyak tertulis dalam undang-undang salah satunya adalah Undang-Undang Dasar Negara tahun 1945 pasal 33 ayat 3, "bumi, air, dan kekayaan alam yang terkandung di dalamnya dikuasai oleh negara dan dipergunakan sebesar-besarnya untuk kemakmuran rakyat". Dari pernyataan tersebut dapat dilihat bahwa hasil pertambangan merupakan suatu kekayaan alam yang diambil atau digali dalam perut bumi, yang dipergunakan untuk mensejahteraan rakyatnya. Akan tetapi tidak terjadi pada masyarakat kecil yang tinggal di sekitar pertambangan.

Hasil penelitian menunjukaan bahwa, dari semua responden memiliki pendapat yang berbeda-beda tentang hukum di sektor pertambangan. Tingkat pengetahuan atau pemahaman responden terhadap hukum sangat rendah. Hal ini dikarenakan responden tidak mengetahui adanya hukum yang mengatur disebabkan karena mereka memiliki keterbatasan untuk menggali informasi karena kesulitan untuk mendapatkan tingkat pendidikan yang berkualitas.

\section{Faktor Ekonomi}

Selain faktor sosial dan hukum, faktor ekonomi juga merupakan salah satu faktor yang memicu adanya aktivitas penambang tanpa izin atau penambang gurandil. Desa Pangkal Jaya merupakan desa dengan areal pertanian yang luas. Bekerja di bidang pertanian tidak mencukupi dalam memenuhi kehidupan sehari hari seperti kebutuhan pangan, maupun pendidikan anak sekolah, sehingga akan menyebabkan masyarakat untuk mencari pekerjaan yang dapat menghasilkan uang dengan cepat salah satunya adalah menjadi penambang gurandil. Berdasarkan hasil penelitian, responden memilih bekerja sebagai gurandil karena berbagai faktor seperti tidak memerlukan modal yang tinggi seperti tingkat pendidikan yang tinggi, keterampilan yang tinggi, mempunyai pengalamn kerja. Hal ini selaras dengan tingkat pendidikan masyarakat di Desa Pangkal Jaya mayoritasnya adalah tidak sekolah atau tidak tamat SD. Jika dilihat hanya beberapa orang yang mempunyai pendidikan sampai Sekolah Menengah Atas/Sederajat. Selain itu pada saat ini, masyarakat tidak tertarik untuk 
bekerja di sektor pertanian karena membutuhkan waktu yang lebih lama. Bekerja sebagai penambang gurandil memiliki resiko yang paling berbahaya yaitu kecelakaan tambang yang akan memyebabkan kematian. Akan tetapi karena masalah ekonomi masyarakat tidak mempunyai pilihan lain untuk mengidupi keluarganya.

Dilihat dari tingkat keterampilan dan keahlian masyarakat khususnya di Desa Pangkal Jaya, keterampilan bekerja yang paling tinggi adalah bertani. Tidak banyak warga yang bekerja dan mempunyai keterampilan yang memadai. Dari responden yang bekerja sebagai penambang gurandil terdapat salah satu anggota keluarga yang bekerja di PT. Antam (Persero) Tbk UPBE Pongkor, karena memiliki keterampilan dan pendidikan yang sesuai syarat minimal untuk bekerja di perusahaan pertambangan. Selain itu faktor ekonomi yang menyebabkan munculnya para penambang gurandil adalah tingkat pengganguran yang tinggi. Pengangguran adalah kondisi dimana seseorang tidak bekerja dan harus bertanggung jawab untuk memenuhi kebutuhan hidup. Menurut BPS (2012) tingkat pengangguran di Kaupaten Bogor mencapai 222 040 orang atau $10.75 \%$ dari jumlah 2175470 angkatan kerja. Jumlah pengangguran di kabupaten bogor naik $0.11 \%$ dari tahun 2010 atau sebanyak 205032 orang $10.64 \%$. pada tahun 2011, pengangguran 222638 orang atau $10.73 \%$ dari total angkata kerja.

Keterbatasan yang dimiliki oleh masyarakat Desa Pangkal Jaya berhubungan erat dengan tingkat pendapatan. Rendahnya pendapatan yang diperoleh dari pekerjaan sebelumnya tidak mencukupi untuk memenuhi kebutuhan seharihari semakin mahal. Hasil penelitian menunjukkan bahwa pekerjaan masyarakat Desa Pangkal Jaya sebelum bekerja sebagai gurandil adalah masih pelajar, tidak bekerja, petani, buruh, dan pedagang asongan.

\section{Aktivitas Pertambangan Emas Tanpa Izin (Gurandil)}

Mayoritas atau 85 persen dari penduduk Desa Pangkal Jaya mempunyai mata pencaharian sebagai penambang gurandil atau tikus yang di dominasi oleh laki-laki setengah baya usia produktif. Akan tetapi masih ada yang bekerja sebagai petani atau buruh tani yang atau pekerjaan lain seperti pedangan sayuran jualan roti. Mereka adalah orang-orang yang sudah tua yang tidak mempunyai fisik yang kuat untuk melakukan penambangan. Tingkat aktivitas penambangan gurandil/tikus dapat diukur dari lama bekerja, frekuensi bekerja, tingkat modal kerja, tingkat keselamatan kerja dan tingkat migrasi dan diklasifikasikn berdasarkan karakteristik gurandil yaitu gurandil cetek (kecil), gurandil biasa, dan gurandil tong.

\section{Tingkat Aktivitas Penambang Gurandil Cetek (Kecil)}

Gurandil cetek (kecil) merupakan gurandil yang paling banyak yang ada di Desa Pangkal Jaya yang biasanya melakukan penambangan selama satu hari (berangkat pagi pulang siang atau sore). Pada umumnya kategori gurandil cetek merupakan penduduk Desa Pangkal Jaya yang berasal dari kalangan anak putus sekolah atau penduduk yang ingin mencoba menjadi penambang karena sebelumnya tidak memiliki pekerjaan. Berdasarkan hasil penelitian, tingginya atau semakin banyaknya gurandil cetek yang melakukan penambangan emas dipicu karena ekonomi yang semakin memburuk yaitu dilihat dari tingkat pendapatan yang tidak mencukupi untuk memenuhi kebutuhan keluarga. Tingkat aktivitas gurandil cetek dalam melakukan penambangan dilihat dari lama bekerja yaitu biasanya melakukan penambanganuntuk menggali bahan tambang selama satu hari (berangkat pagi pulang siang/sore) serta melakukan pengolahan dari bahan tambang menjadikan kepingan emas sekitar 6 jam. Dalam melakukan penambangan emas gurandil cetek hanya menggunakan peralatan yang sederhana seperti senter, pahat dan palu serta karung goni untuk mengumpulkan hasil tambang.

$$
\begin{aligned}
& \text { Ya teh, gurandil kaya saya biasanya pergi pagi dan } \\
& \text { pulang siang. Setelah itu langsung ngolah sendiri. } \\
& \text { Biasanya nambang di lobang kecil dan tidak } \\
& \text { dalam, ya cukup untuk sehari-harilah hasilnya. Dan } \\
& \text { alatnya Cuma senter, pahat, palu dan karung goni. } \\
& \text { Ya paling sehari dapet 3-4 karung goni (HD, } \\
& \text { 2014). }
\end{aligned}
$$

Pengolahan untuk menjadikan kepingan emas, gurandil cetek menggunakan alat yang disebut "gelundungan" akan tetapi tidak semua gurandil memiliki alat tersebut. Gurandil cetek yang tidak memilki gelundungan melakukan pengolahan di tempat orang lain dengan status menyewa dan membutuhkan uang untuk membayarnya. Akan tetapi gurandil yang mempunyai alat pengolahan 
sendiri lebih memiliki modal yang kecil untuk melakukan pengolahannya. Setelah melakukan pengolahan menjadi kepingan emas gurandil tersebut dapat menjual kepingan emas dan menggunakan untuk memenuhi kebutuhan sehari-hari keluarga.

Karakteristik gurandil cetek juga dapat dilihat dari frekuensi melakukan penambangan emas dalam sebulan terakhir. Frekuensi bekerja adalah hari yang di gunakan gurandil cetek untuk melakukan penambangan emas dalam satu bulan terakhir. Berdasarkan hasil penelitian, dalam sebulan terakhir gurandil cetek melakukan penambangan sekitar 8-16 kali. Dalam melakukan penambangan gurandil juga melihat kondisi lingkungan seperti cuaca yang tidak mendukung yang akan membahayakan keselamatan diri. gurandil juga melihat kondisi lingkungan seperti cuaca yang tidak mendukung yang akan membahayakan keselamatan diri. Modal kerja hanya memerlukan dan menggunakan peralatan sederhana yaitu pahat, palu dan karung goni. Untuk memenuhi peralatan tersebut gurandil cetek tidak perlu mengeluarkan biaya besar karena alat alat tersebut mudah untuk didapatkan dengan harga murah. Akan tetapi jika modal kerja seperti alat alat tersebut tidak ada maka gurandil, baik gurandil cetek maupun gurandil biasa tidak bisa melakukan penambangan.

\footnotetext{
"Ya neng, mau gimana lagi, jadi gurandil mah untung-untungan. Kadang untung, kadang rugi. Untungnya sekali, ruginya lima kali. Belum lagi buat bayar utang buat modal pertama ke gunung. Ya segitulah dapatnya buat makan saja cukup alhamdulillah. Kadang pulang dari gunung ga bawa apa-apa karena gunung nya lagi ga bagus padalah badan udah sakit-sakit". (AU, 2014)
}

Selain modal, karakteristik gurandil cetek dapat dilihat dari cara menjual hasil galiannya. Salah satu caranya adalah menjual hasil galiannya dalam bentuk bahan galian mentah yaitu batubatuan/tanah yang telah dikumpulkan dalam karung goni ke bandar/pengumpul atau gurandil tong. Bandar/pengumpul tersebut merupakan bandar-bandar kecil penyandang dana yang dapat menikmati hasil tanpa harus menghadapi resiko kematian seperti tertimbun tanah longsor, terjebak asap bakaran, atau bentrok dengan aparat perusahaan. Selain itu cara gurandil cetek menjual hasil galiannya adalah dengan menjual hasil dalam bentuk kepingan emas. Akan tetapi, kepingan emas tersebut tidak memiliki nilai yang tinggi karena kadar yang terkandung di dalamnya rendah.

\section{Tingkat Aktivitas Penambang Gurandil Biasa}

Gurandil biasa merupakan karakteristik gurandil yang melakukan penambangan untuk mendapatkan atau memperoleh hasil tambang menggunakan waktu sekali penambangan 3 sampai 6 hari dalam satu minggu. Gurandil tersebut biasa biasa disebut dengan sebutan gurandil bukan gurandil biasa. Hasil penelitian menunjukkan bahwa dalam proses melakukan penambangan dengan cara berkelompok. Dalam satu kelompok biasanya terdiri dari 3 sampai 4 orang yang akan melakukan penambangan dalam lubang. Anggota kelompok tersebut merupakan orang-orang atau gurandil yang juga memiliki hubungan keluarga atau juga berasal dari daerah lain. Dalam melakukan pengolahan menjadi kepingan emas, gurandil biasa menggunakan waktu lebih kurang satu hari tergantung kekerasan bahan galian yang diperoleh. Selain itu, bahan galian yang diperoleh lebih banyak dibandingkan dengan gurandil cetek.

\footnotetext{
"Proses pengolahan menjadi kepingan emas dimulai dari tahap pertama dengan cara menghancurkan batu/tanah yang telah digali dari gunung menggunakan palu, setelah hancur dimasukkan ke dalam gelundungan selama 4 sampai 6 jam. Paling kurang selama 4 jam tergantung kekerasan batu. Setelah itu akan terlihat butiran-butiran emas dan pisahkan dengan lumpur, karena nantinya lumpur bisa diolah lagi menjadi perak. Selanjutnya dilakukan proses peleburan sampai kering kira-kira 30 menit sampai menjadi bahan urat karang (seperti pasir) setelah itu diolah lagi dengan mencampurkan raksa + air selama 3 jam. Selanjutnya ditumbuk, disaring dipisahkan dengan merkuri untuk mendapatkan emas sesuai kadarnya. Setelah itu dilakukan pembakaran (digebos), dimasukin ke dalam air, di pukul (digeprek) untuk mendapatkan kepingan, di bakar lagi selama 10 menit untuk mendapatkan merapikan kepingan emas, di pukul (digeprek) lagi sampai benar-benar rapi sehingga dapat kepingan yang bagus dan langkah selanjutnya di timbang untuk di jual". (UN, 2015)
}

Proses pengolahan bahan galian tersebut menggunakan bahan kimia berbahaya seperti merkuri dan sianida, secara kesehatan akan menggangu atau membahayakan keselamatan diri penambang. Penambang cetek, gurandil biasa maupun gurandil tong dengan mudah memperoleh bahan tersebut. Hasil penelitian menunjukkan bahwa bahan yang digunakan 
dalam pengolahan emas tersebut dapat diperoleh di pasar dan di toko/warung biasa. Bahan-bahan yang mudah diperoleh tersebut menjadikan gurandil lebih mudah dalam pengolahan menjadi keingan emas.

Berdasarkan frekuensi bekerja yang dilakukan oleh gurandil biasa, hasil penelitian menunjukkan bahwa gurandil biasanya pada umumnya melakukan penambangan ke Gunung Pongkor dalam satu bulan terakhir 2-6 kali. Hal ini disebabkan oleh waktu yang digunakan dalam satu kali penambangan lebih lama. berdasarkan hasil penelitian rata-rata gurandil melakukan penambangan yaitu 4 kali dalam sebulan terakhir. Karakteristik gurandil biasa juga terlihat dari penghasilan yang diperoleh lebih besar dibandingkan gurandil cetek yang digunakan selain untuk memenuhi kebutuhan sehari hari juga digunakan untuk memenuhi kebutuhan sekunder atau kebutuhan tersier. Hal tersebut dapat dilihat dari kondisi bangunan rumah dan kepemilikan peralatan serta kepemilikan aset kendaraan yang lebih baik dibandingkan gurandil cetek.

Dilihat dari tingkat modal kerja yang dibutuhkan gurandil biasa sama halnya dengan gurandil biasa yang menggunakan pahat, palu, linggis dan karung goni. Akan tetapi gurandil biasa memiliki modal yang lebih besar yaitu untuk memenuhi kebutuhan hidup seperti makan dan kebutuhan lainnya selama gurandil tersebut barada di dalam lubang galian. Para gurandil tersebut membawa bekal logistik, mulai dari beras, mie, garam, ikan asin, rokok, dan juga peralatan memasak untuk memenuhi kebutuhan. Mengendap di perut bumi atau di lubang galian selama 3 sampai 6 hari tersebut salah satunya dengan tujuan mnghindari kejaran aparat keamanan perusahaan. Setelah melakukan penggalian bahan tambang, secara berangsurangsur diangkut keluar lubang menggunakan tenaga penggangkut seperti kuli pikul. Setelah terkumpul bahan galian tersebut dibagi rata dengan anggota kelompok karena dalam melakukan penggalian secara berkelompok dan selanjutnya bahan tersebut diangkut ke tempat pengolahan masing-masing dengan menggunakan mobil angkutan.

Berdasarkan relasi atau jaringan yang dimiliki oleh gurandil biasa, tergolong luas dan kuat antara sesama gurandil atau kelompok gurandil. Pada umumnya satu kelompok gurandil memiliki jaringan dengan pihak keamanan perusahaan dan untuk masuk ke dalam lubang bekas, mereka harus menyuap atau memberikan uang pada pihak keamanan setempat. Besaran yang diberikan tergantung pihak yang bersangkutan, akan tetapi biasanya berkisar 1 000000 sampai 2000000 per kelompok.

\section{Tingkat Aktivitas Penambang Gurandil Tong}

Gurandil tong merupakan gurandil yang tidak melakukan penambangan ke Gunung yaitu Gunung Pongkor, akan tetapi memiliki tempat pengolahan bahan galian menjadi kepingan emas. Gurandil tong lebih identik dengan bos (atasan) dan memiliki posisi yang sedikit aman dibandingan gurandil cetek dan gurandil biasa. Hal ini karenakan oleh guradil tong tidak harus menghadapi bahasa seperti tertimbun longsor, terjebak asap bakaran, atau bentrok dengan aparat perusahaan dan bahaya lainnya yang berhubungan dengan lokasi penggalian bahan tambang. Gurandil tong pada umumnya mempunyai anak buah atau pekerja untuk melakukan baik penambangan ke gunung maupun dalam melakukan pengolahan menjadi kepingan emas. Sebelum menjadi gurandil tong, gurandil tersebut merupakan gurandil kecil atau gurandil biasa yang pada akhirnya memiliki modal yang lebih banyak untuk menyediakan tempat pengolahan atau lebih dikenal dengan sebutan tong. Gurandil tong dicirikan dengan penghasilan yang diperoleh lebih besar dari pada gurandil biasa. Hal ini terlihat bahwa gurandil ini memiliki satu atau dua orang karyawan atau pekerja yang diupah per hari atau per minggu. Dari hasil tersebut gurandil tong memperoleh kehidupan yang lebih memadai seperti kondisi bangunan tempat tinggal. Cara kerja gurandil tong atau cara dalam pengolahan bahan tambang menjadi kepingan emas lebih baik dari pada gurandil cetek maupun gurandil biasa. Gurandil tong memiliki tenpat pengolahan yang besar dan memiliki tempat yang luas yang sering disebut tong. Dari hasil pengolahan tersebut gurandil tong memperoleh kepingan emas dengan berat dan kadar yang bagus. Bahan galian tersebut diolah dengan menggunakan bahan kimia beracun seperti sianida dan merkuri akan tetapi dalam membentuk kepingan emas yang bagus menggunakan ketelitian dan waktu yang cukup lama agar kepingan yang dihasilkan berkualitas tinggi dan dijual dengan harga yang tinggi. Dari 
keuntungan tersebut, gurandil tong memilki penghasilan yang lebih besar dibandingkan gurandil cetek dan gurandil biasa.

Gurandil tong memilki relasi yang kuat antar sesama maupun pihak luar seperti halnya dengan pihak bandar emas. Setelah kepingan emas diperoleh, kepingan tersebut dijual ke tempat penjual emas resmi dengan harga sesuai harga emas dunia. Untuk mengetahui harga emas terbaru gurandil tong memanfaatkan jaringan antar sesama gurandil tong maupun dengan menggunakan media masa seperti televisi.

Selain itu, tingginya tingkat aktivitas gurandil juga dapat dilihat dari tingkat keselamatan diri sebagai penambang. Berdasarkan hasil penelitian, pada umumnya responden menyadari akan tingginya bencana yang dihadapi. Akan tetapi, potensi yang ada untuk memperoleh penghasilan untuk memenuhi kebutuhan sehari hari dengan tingkat keterampilan dan pendidikan yang rendah adalah bekerja sebagai penambang gurandil atau tikus. Indikator terakhir yang dapat menentukan tingkat aktivitas penambang gurandil dalam melakukan penambangan adalah tingkat migrasi. Migrasi merupakan perpindahan penduduk dari suatu tempat ke tempat yang lain melewati batas administrasi. Migrasi ini ingin melihat berapa banyak masyarakat yang datang atau masuk ke Desa Pangkal Jaya, Kecamatan Nanggung, Kabupaten Bogor semenjak meluasnya kegiatan penambangan tanpa izin atau penambang gurandil/tikus. Pada penelitian ini, rumah tangga di Desa Pangkal Jaya dilihat dari asal kependudukannya dibedakan menjadi dua kategori yaitu penduduk asli dan penduduk pendatang. Penduduk asli dalam penelitian ini adalah setiap orang yang lahir dan tinggal di Desa Pangkal Jaya dan penduduk pendatang adalah setiap orang yang lahir bukan dari Desa Pangkal Jaya tetapi tinggal di desa tersebut.

Dari hasil penelitian tingkat aktivitas penambang gurandil yang berasal dari Desa Pangkal Jaya dari tahun ke tahun tergolong meningkat. Dapat dilihat dari banyaknya orang yang berdatangan ke desa untuk menetap dan bekerja sebagai penambang gurandil/tikus. Desa Pangkal Jaya menjadi target migrasi karena mempunyai keunggulan dibandingkan dengan desa desa lain di Kecamatan Nanggung yaitu jarak yang tidak terlalu jauh dengan lokasi penambangan di Gunung Pongkor dengan mempertimangkan biaya transportasi dan akomodasi untuk melakukan penambangan. Selain itu juga dapat dilihat dari tingginya resiko dan bahaya yang tidak bisa diprediksi kapan terjadi bencana tidak menyurutkan niat penambang untuk melakukan penambangan. Aktivitas gurandil paling tinggi terlihat dari gurandil cetek. Dapat juga dilihat dari frekuensi bekerja sebulan terakhir yang tergolong tinggi.

\section{Kesejahteraan Rumah Tangga Gurandil}

Kesejahteraan merupakan kondisi relatif yang diciptakan oleh masyarakat melalui interaksi sosial untuk memenuhi kebutuhan jasmaniah, rohani, dan sosial mereka. Untuk menentukan tingkat kesejahteraan rakyat Badan Pusat Statistik tahun 2005 menggunakan berbagai indikator antara lain: tingkat pendidikan, tingkat kesehatan, kondisi perumahan (jenis lantai, luas bangunan rumah, jenis dinding bangunan, dan lain-lain), tingkat pendapatan, dan tingkat pengeluaran.

\section{Tingkat Kesejahteraan Penambang Gurandil Cetek}

Tingkat kesejahteraan juga dapat dilihat dari kondisi tempat tinggal. Hasil penelitian menunjukan bahwa terjadinya perubahan kondisi tempat tinggal masyarakat Desa Pangkal Jaya ke arah tergolong layak atau bagus setelah bekerja sebagai penambang gurandil/tikus. Hal ini dapat dilihat dari berbagai indikator seperti perubahan jenis lantai, jenis dinding, luas bangunan tempat tinggal, dan lain lain.

Berdasarkan status kepemilikan rumah, terdapat peningkatan ke arah yang positif atau ke arah yang lebih baik setelah masyarakat atau responden bekerja sebagai penambang gurandil. Perubahan terjadi pada status kepemilikan tempat tinggal adalah milik sendiri. Sedangkan berdasarkan jenis lantai rumah, terjadi perubahan yang semakin meningkat dari jenis lantai keramik dengan peningkatan $63.00 \%$ dan jenis lantai kayu murah, bambu dan tanah setelah bekerja sebagai gurandil tidak ada responden yang memiliki jenis lantai rumah tersebut. Dapat disimpulkan bahwa jenis lantai kayu, bambu serta tanah mengalami penurunan sebesar $100.00 \%$. Dilihat dari jenis dinding pada umumnya sebelum dan sesudah bekerja sebagai gurandil terbuat dari tembok beton. Sumber air minum rumah tangga di Desa Pangkal Jaya tahun 2015 lebih banyak menggunakan sumur pomba/bor 
Kesehatan merupakan hal yang sangat penting untuk diperhatikan oleh siapapun termasuk gurandil. Kondisi tubuh harus dijaga dan dilindungi aga tidak terserang penyakit yang dapat datang kapan saya atau tidak mengenal waktu. Penyakit tersebut dapat disebabkan oleh kondisi lingkungan yang tidak sehat, gaya hidup yang tidak sehat, makan tidak teratur, dan lainlain. Hasil penelitian menunjukkan bahwa tingkat kesehatan gurandil cetek setelah bekerja sebagai gurandil menurun sebesar $73.00 \%$ serta responden yang terkena penyakit demam/batuk meningkat sebesar $\quad 140.00 \%$. Rata-rata masyarakat di Desa Pangkal Jaya menggunakan jasa puskesmas untuk berobat agar penyakit yang diderita cepat sembuh. Akan tetapi dengan semakin banyaknya masyarakat yang bekerja sebagai gurandil menyebabkan jasa yang digunakan tidak hanya puskesmas antara lain praktek dokter, rumah sakit, dan obat alternatif. Dilihat dari aset kepemilikan alat transportasi yang dimiliki oleh gurandi cetek meningkat terlihat dari semakin banyak responden yang memiliki kendaraan. Kesejahteraan berkaitan erat dengan pemenuhan kebutuhan dasar seperti kebutuhan pangan, sandang dan papan. Untuk memenuhi kebutuhan tersebut faktor yang sangat menentukan adalah tingkat pendapatan yang diperoleh oleh anggota keluarga yang bekerja per bulan.

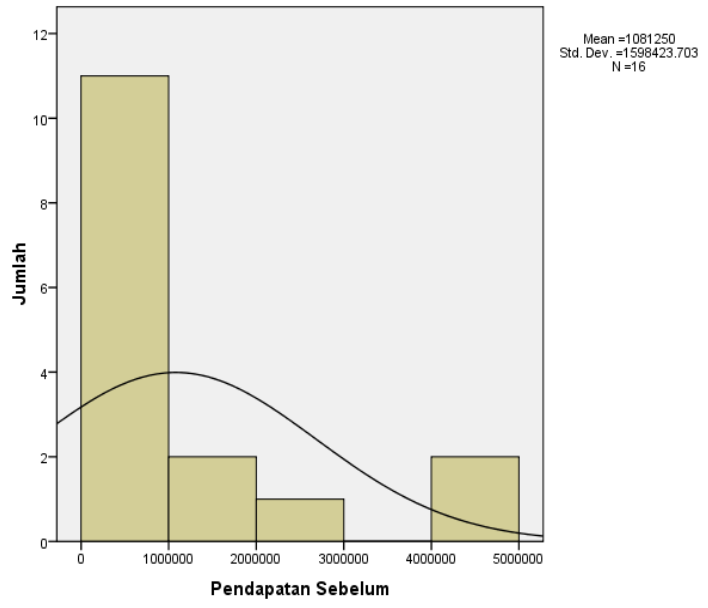

Gambar 2 Grafik jumlah pendapatan sebelum menjadi gurandil di Desa Pangkal Jaya tahun 2015

Tingkat pendapatan yang diperoleh oleh gurandil cetek, digolongkan menjadi tiga kategori yaitu tinggi, sedang dan rendah. Berdasarkan hasil penelitian, tingkat pendapatan sebelum bekerja sebagai gurandil cetek tergolong rendah apabila pendapatan yang diperoleh kecil dari Rp 282038 yaitu terdapat 7 orang responden atau $43.80 \%$, tingkat pendapatan tergolong kategori sedang apabila pendapatan yang diperoleh antara Rp 282038 hingga lebih kecil dari Rp 1880461 yaitu terdapat 6 orang responden atau $37.50 \%$, dan kateori tinggi apabila pendapatan yang diperoleh lebih besar dari Rp 1880461 yaitu terdapat 3 orang responden atau $18.70 \%$.

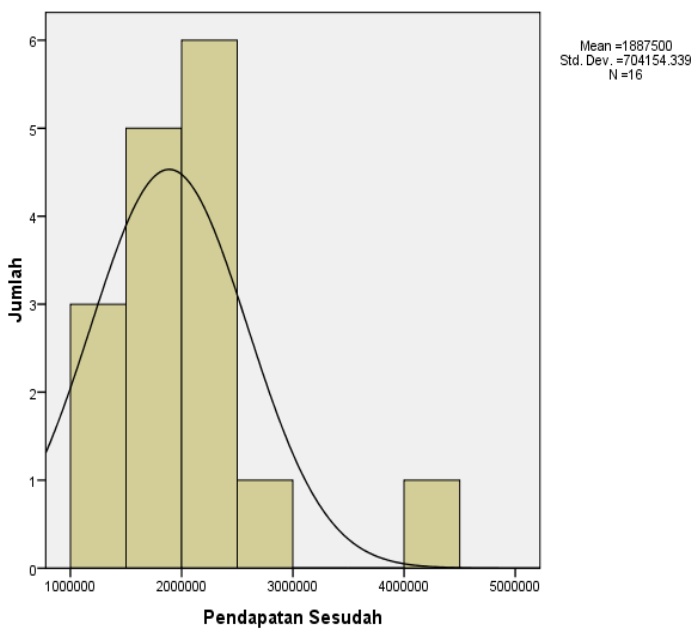

Gambar 3 Grafik jumlah pendapatan sesudah menjadi gurandil di Desa Pangkal Jaya tahun 2015

Hasil penelitian menunjukkan bahwa tinggat pendapatan gurandil setelah menjadi gurandil cetek pada umumnya tergolong rendah yaitu lebih kecil dari Rp 1535 422. Pendapatan yang diperoleh oleh gurandil cetek di Desa Pangkal Jaya menunjukkan bahwa adanya perbedaan antara sebelum dan sesudah menjadi gurandil cetek. Hal ini disebabkan oleh adanya perbedaan atau kesenjangan sosial serta perubahan yang terjadi antara sebelum dan sesudah menjadi gurandil seperti adanya kenaikan harga emas setelah bekerja sebagai gurandil. Berdasarkan data tersebut dapat ditarik kesimpulan, walaupun meningkatnya jumlah responden yang memperoleh tingkat pendapatan rendah, pada kenyataannya jumlah pendapatan yang diperoleh responden setelah menjadi gurandil dikatakan meningkat karena range antara kategori rendah sebelum dan sesudah menjadi gurandil lebih tinggi.

Dalam penelitian ini, pengeluaran yang dihitung adalah pengeluaran dalam satu tahun terakhir 


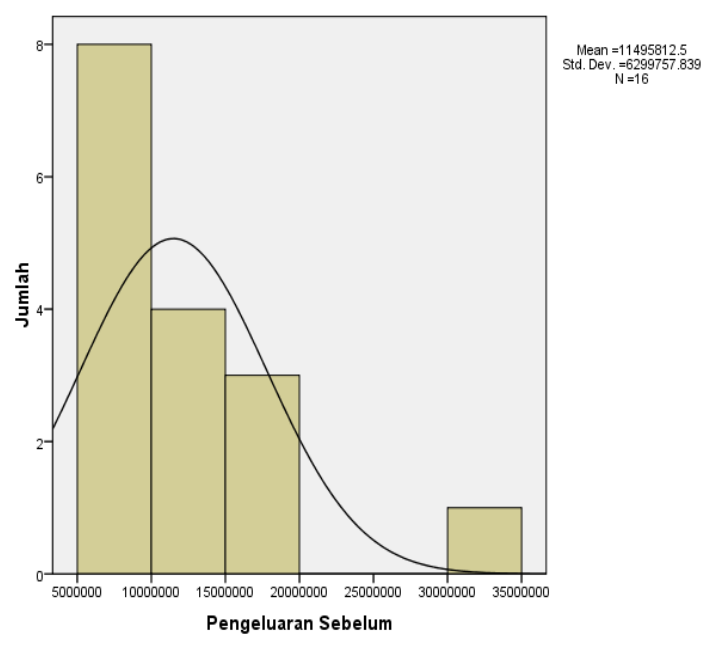

Gambar 4 Grafik jumlah pengeluaran sebelum menjadi gurandil di Desa Pangkal Jaya tahun 2015

Dari data tersebut rata-rata responden menggeluarkan biaya pada kategori rendah yaitu lebih kecil dari Rp 8345933 per tahun.

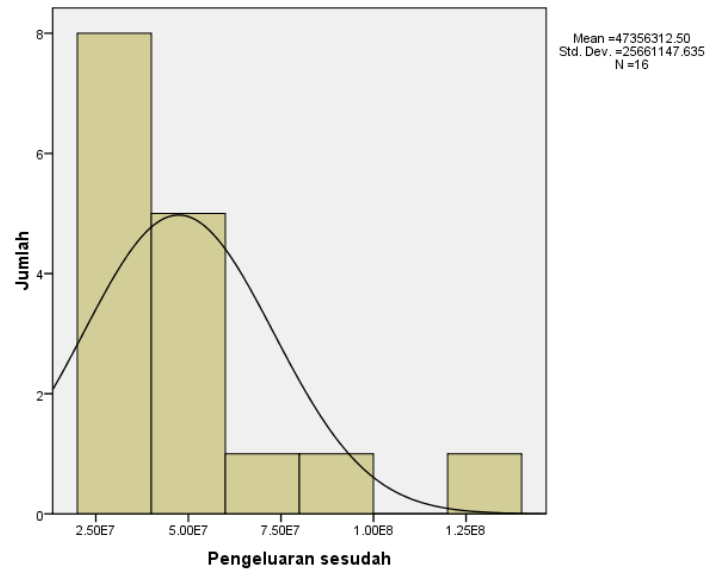

Gambar 5 Grafik jumlah pengeluaran sesudah menjadi gurandil di Desa Pangkal Jaya tahun 2015

Dari data tersebut rata-rata responden menggeluarkan biaya pada kategori rendah yaitu lebih kecil dari Rp 8345933 per tahun. Meningkatnya jumlah pengeluaran yang dikeluarkan gurandil cetek disebabkan oleh kebutuhan pokok maupun kebutuhan lainnya mengalami kenaikan harga dan juga kebutuhan hidup yang sudah beragam.

\section{Tingkat Kesejahteraan Penambang Gurandil Biasa}

Tingkat kesejahteraan gurandil biasa jika dilihat dari status kepemilikan rumah sebelum menjadi gurandil 7 orang responden atau $87.50 \%$ tinggal bersama orang tua. Akan tetapi setelah bekerja sebagai gurandil biasa 4 dari 8 orang responden gurandil biasa telah memiliki tempat tinggal dengan status milik sendiri, dan 4 orang responden lainnya masih tinggal di rumah dengan status kepemilikan milik orang tua dan atasan. Jika dilihat dari jenis lantai rumah, setelah responden bekerja sebagai gurandil biasa, jenis lantai yang dimiliki berubah $100.00 \%$ menjadi keramilk. Hal ini menunjukkan peningkatan ke arah yang lebih baik atau sejahtera. Dan terlihat bahwa sebelum dan sesudah menjadi gurandil biasa jenis dinding yang dimiliki oleh gurandil biasa terbuat dari tembok beton. Merujuk pada sumber air minum yang dignakan gurandil biasa tidak mengalami perubahan. Hal ini terlihat dari hasil penelitian gurandil biasa tetap menggunakan mata air dan sumur bor/pompa sebagai sumber air minum untuk keluarga. Fasilitas MCK yang digunakan sebelum bekerja sebagai gurandil biasa pada umumnya menggunakan WC umum dan WC pribadi semen. Setelah memiliki sedikit demi sedik pendapatan dari hasil gurandil, fasilitas MCK yang digunakan lebih banyak WC pribadi keramik yaitu 5 orang responden atau $62.50 \%$ dan 2 orang responden mnggunakan WC umum serta 1 orang responden menggunakan WC pribadi semen.

Perubahan terlihat dari aset kepemilikan alat transportasi yang dimiliki oleh gurandil biasa. Sebelum responden bekerja sebagai gurandil dalam hal ini adalah gurandil biasa, 7 dari 8 orang responden belum memiliki alat transportasi seperti sepeda motor. Akan tetapi perubahan terjadi setelah bekerja sebagai gurandil 7 dari 8 orang respnden memiliki alat transportasi yaitu sepeda motor. Sedangkan tingkat kesehatan yang terjadi pada gurandil biasa di Desa Pangkal Jaya mengalami penurunan. Terjadi bahwa perubahan terjadi setelah responden bekerja sebagai gurandil tingkat kesehatan menurun 33.00\%. Berdasarkan tempat berobat, setelah bekerja sebagai gurandil menggunakan jasa rumah sakit dan praktek dokter. Hal tersebut tidak mengalami perubahan yang signifikan dibandingkan sebelum bekerja sebagai gurandil. Dengan jasa tempat berobat pada umumnya menggunakan puskesmas dan praktek dokter. 


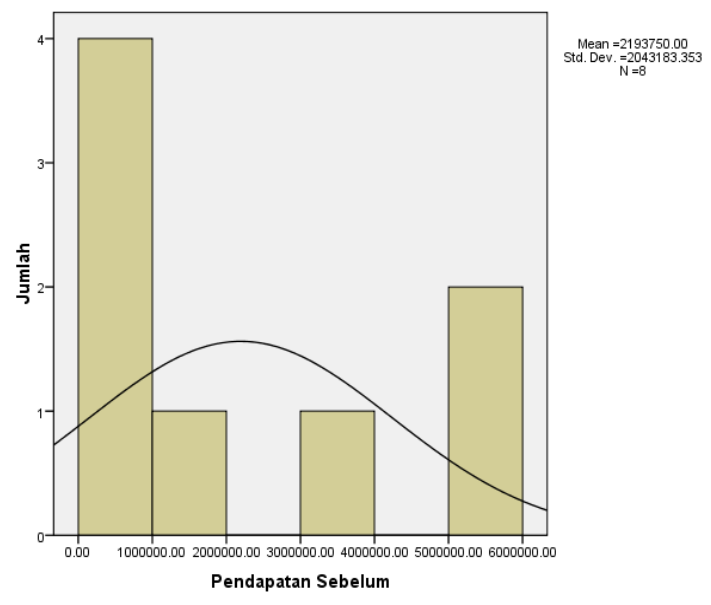

Gambar 6 Grafik jumlah pendapatan sebelum menjadi gurandil di Desa Pangkal Jaya tahun 2015

Berdasarkan hasil penelitian, tingkat pendapatan sebelum bekerja sebagai gurandil biasa tergolong rendah apabila pendapatan yang diperoleh kecil dari Rp 1172158 yaitu terdapat 4 orang responden atau $50.00 \%$, tingkat pendapatan tergolong kategori sedang apabila pendapatan yang diperoleh antara Rp 1172158 hingga lebih kecil dari Rp 3215341 yaitu terdapat 2 orang responden atau $25.00 \%$, dan kateori tinggi apabila pendapatan yang diperoleh lebih besar dari Rp 3215341 yaitu terdapat 2 orang responden atau $25.00 \%$.

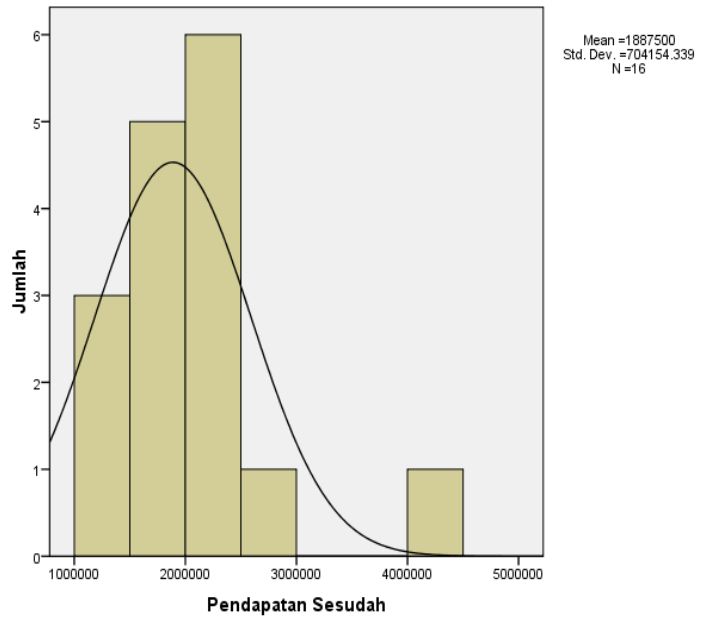

Gambar 7 Grafik jumlah pendapatan sesudah menjadi gurandil di Desa Pangkal Jaya tahun 2015

Setelah bekerja menjadi gurandil biasa, tingkat pendapatan gurandil biasa tergolong rendah apabila pendapatan yang diperoleh per bulan lebih kecil dari Rp 6174568 yaitu 3 orang responden atau $37.50 \%$, tergolong sedang apabila pendapatan yang diperoleh antara Rp 6 174568 hingga lebih kecil dari Rp 14200731 yaitu 4 orang responden atau $50.00 \%$, dan tergolong tinggi apabila pendapatan yang diperoleh lebih besar dari Rp 14200731 yaitu 1 orang responden atau $12.50 \%$. Hasil penelitian menunjukkan bahwa tinggat pendapatan gurandil setelah menjadi gurandil biasa lebih banyak tergolong kategori sedang. Pendapatan yang diperoleh oleh gurandil biasa di Desa Pangkal Jaya menunjukkan bahwa adanya peningkatan ke arah yang lebih baik dan tingkat pendapatan lebih tinggi.

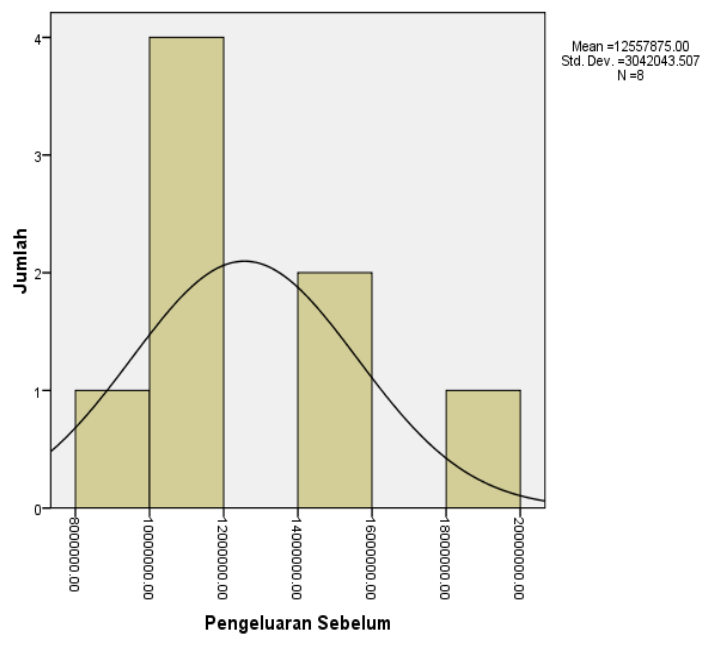

Gambar 8 Grafik jumlah pengeluaran sebelum menjadi gurandil di Desa Pangkal Jaya tahun 2015.

Berdasarkan hasil penelitian sebelum bekerja sebagai gurandil biasa, pengeluaran tergolong kategori rendah apabila tingkat pengeluaran yang dikeluarkan lebih kecil dari Rp 11036 853.25 per tahun, pengeluaran tergolong kategori sedang apabila mengeluarkan biaya antara Rp 11036853.25 hingga lebih kecil dari Rp 14078896.75 dan tergolong tinggi apabila lebih besar dari Rp14 078 896.75. Hasil penelitian menunjukkan 4 orang responden atau $50.00 \%$ termasuk ke dalam kategori rendah, sebanyak 1 orang responden atau $12.50 \%$ termasuk ke dalam kategori sedang, dan 3 orang responden atau $37.50 \%$ memiliki pengeluaran kategori tinggi. 


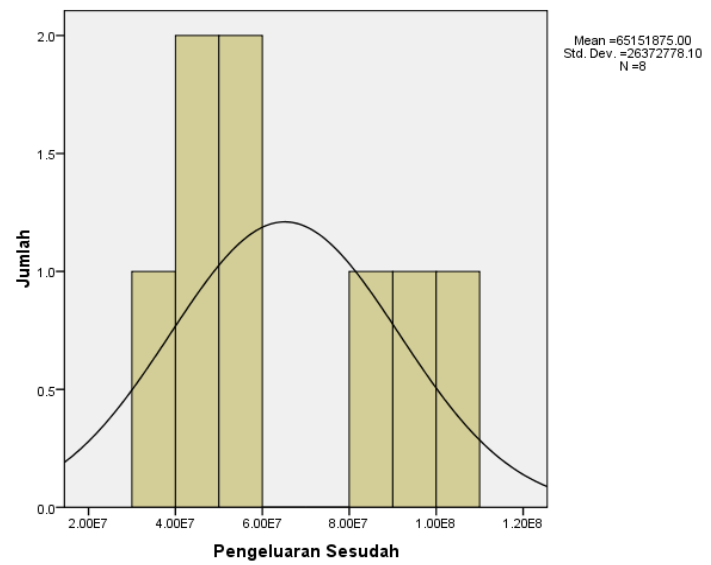

Gambar 9 Grafik jumlah pengeluaran sesudah menjadi gurandil di Desa Pangkal Jaya tahun 2015

Berdasarkan hasil penelitian sesudah bekerja sebagai gurandil biasa, pengeluaran tergolong kategori rendah apabila pengeluaran yang dikeluarkan lebih kecil dari Rp 51965485 per tahun, pengeluaran tergolong kategori sedang apabila mengeluarkan biaya antara Rp 51965 485 hingga lebih kecil dari Rp 78338264 dan tergolong tinggi apabila lebih besar dari 78338 264. Hasil penelitian menunjukkan 3 orang responden atau $37.50 \%$ termasuk ke dalam kategori rendah, sebanyak 2 orang responden atau $25.00 \%$ termasuk ke dalam kategori sedang, dan 3 orang responden atau $37.50 \%$ memiliki pengeluaran kategori tinggi. Jumlah pengeluaran yang dikeluarkan oleh gurandil untuk memenuhi kebutuhan pribadi dan keluarganya dapat disimpulkan meningkat dari sebelum hingga sesudah menjadi gurandil. Hal ini disebabkan oleh kebutuhan semakin beragam dan kebiasaan masyarakat desa yang konsumtif.

\section{Tingkat Kesejahteraan Penambang Gurandil Tong}

Tingkat kesejahteraan gurandil tong lebih baik dibandingkan dengan gurandil cetek maupun gurandil gurandil biasa jika dilihat dari kondisi fisik rumah dan tingkat pendapatan. Tingkat kesejahteraan gurandil tong jika dilihat dari kondisi fisik rumah seperti status kepemilikan rumah, gurandil tong lebih banyak memiliki rumah dengan status milik sendiri. Perubahan signifikan terlihat pada jenis lantai rumah yang dimiliki gurandil setelah bekerja sebagai gurandil tong adalah kemamik yaitu 8 orang responden atau $100.00 \%$. jika sebelum menjadi gurandil tong jenis lantai yang dimiliki terbuat dari bambu dan semen. Sebelum bekerja sebagai gurandil tong, jenis dinding rumah yang dimiliki terbuat dari bambu, bata dan beton. Jika dilihat setelah responden bekerja sebagai gurandil tong, jenis dinding rumah yang dimiliki pada umumnya adalah tembok beton.

Tabel 1 Perubahan jumlah dan persentase responden gurandil tong berdasarkan status kepemilikan rumah di Desa Pangkal Jaya tahun 2015

\begin{tabular}{lcccccc}
\hline \multirow{2}{*}{ Indikator } & \multicolumn{2}{c}{ Sebelum } & \multicolumn{2}{c}{ Sesudah } & \multicolumn{2}{c}{ Perubahan } \\
\cline { 2 - 7 } & $\mathrm{n}$ & $\%$ & $\mathrm{n}$ & \multicolumn{1}{c}{$\%$} & $\mathrm{n}$ & \multicolumn{1}{c}{$\%$} \\
\hline Milik & 1 & 12.5 & 6 & 75.0 & 5 & 500.0 \\
Sendiri & & & & & & \\
Kontrak & 1 & 12.5 & 0 & 0.0 & -1 & 100.0 \\
Milik & 6 & 75.0 & 2 & 25.0 & -0.67 & -67.0 \\
Orang Tua/ & & & & & & \\
Sanak & & & & & & \\
\hline Total & 8 & 100.0 & 8 & 100.0 & & \\
\hline
\end{tabular}

Keterangan: (-) menurun

Hasil penelitian menunjukkan bahwa tidak terdapat perubahan yang signifikan berdasarkan sumber air minum yang digunakan untuk keluarga gurandil tong yaitu tetap menggunakan air sumur. Perubahan terlihat dalam menggunakan fasilitas MCK terjadi pada penggunaan WC umum dan WC pribadi keramik. Sebelum menjadi gurandil tong $87.50 \%$ responden menggunakan WC umum dan tidak ada yang menggunakan WC pribadi keramik. Akan tetapi setelah menjadi gurandil $62.50 \%$ responden menggunakan $\mathrm{WC}$ pribadi keramik dan penggunaan $\mathrm{WC}$ umum menurun menjadi $12.50 \%$.

Perubahan terjadi signifikan terjadi setelah menjadi gurandil tong yaitu pada umumnya responden memilki alat transportasi yaitu 5 orang atau $62.50 \%$ memilki sepeda motor, 2 orang atau $25.00 \%$ memiliki sepeda dan 1 orang responden atau $12.50 \%$ memiliki mobil pribadi. Hal tersebut dapat disimpulkan bahwa setelah menjadi gurandil tong kehidupan menjadi lebih baik jika dilihat dari aset kepemilikan alat transportasi yang dimiliki. Tingkat kesehatan setelah menjadi gurandil tong dapat disimpulkan menurun. Hal ini terlihat dari kesehatan responden mengalami penurunan $80.00 \%$. dan penyakit yang diderita yaitu batuk/demam meningkat menjadi $87.50 \%$. jika dilihat berdasarkan jasa yang digunakan untuk berobat lebih banyak menggunakan jasa praktek dokter. Hal ini disebabkan karena tingkat pendapatan yang diperoleh gurandil tong lebih besar dan 
mencukupi untuk berobat ke praktek dokter maupun yang lainnya. Tingkat kesejahteraan suatu masyarakat atau komunitas dapat juga dilihat dari tingkat pendpatan dan tingkat pengeluaran. Berdasarkan hasil penelitian dapat dilihat tingkat pendapatan gurandil tong sebelum dan sesudah menjadi gurandil tong.

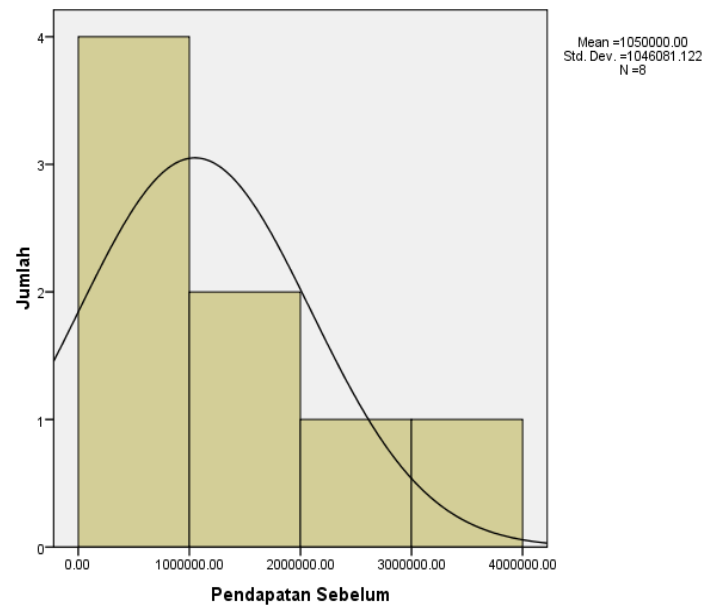

Gambar 10 Grafik jumlah pendapatan sebelum menjadi gurandil di Desa Pangkal Jaya tahun 2015

Sesudah bekerja sebagai gurandil tong, tingkat pendapatan semakin meningkat. Peningkatan jumlah pendapatan tersebut didorong oleh jenis pekerjaan yang mereka lakukan dan harga hasil olahan seperti kepingan emas semakin meningkat.

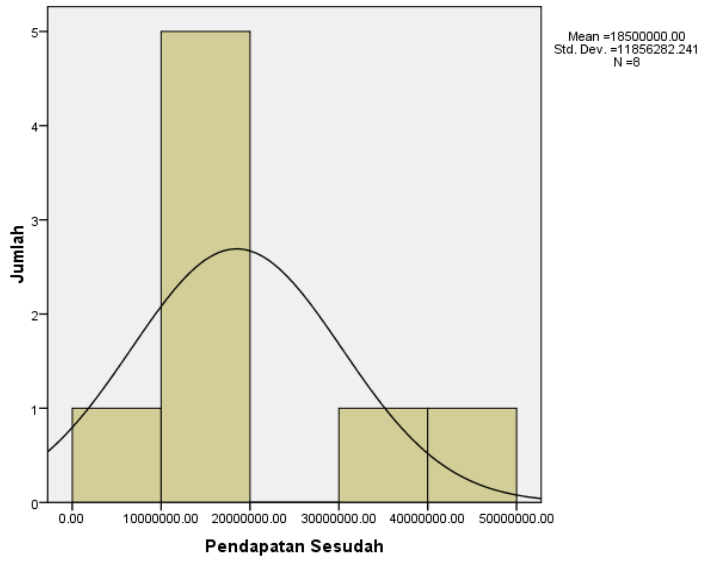

Gambar 11 Grafik jumlah pendapatan sesudah menjadi gurandil di Desa Pangkal Jaya tahun 2015

Berdasarkan hasil penelitian sebelum bekerja sebagai gurandil tong, pengeluaran tergolong kategori rendah apabila tingkat pengeluaran yang dikeluarkan lebih kecil dari Rp 10932589 per tahun, pengeluaran tergolong kategori sedang apabila mengeluarkan biaya antara $\mathrm{Rp} 10$ 932589 hingga lebih kecil dari Rp 15667160 dan tergolong tinggi apabila lebih besar dari Rp 15667 160. Hasil penelitian menunjukkan 2 orang responden atau $25.00 \%$ termasuk ke dalam kategori rendah, sebanyak 5 orang responden atau $62.50 \%$ termasuk ke dalam kategori sedang, dan 1 orang responden atau $12.50 \%$ memiliki pengeluaran kategori tinggi.

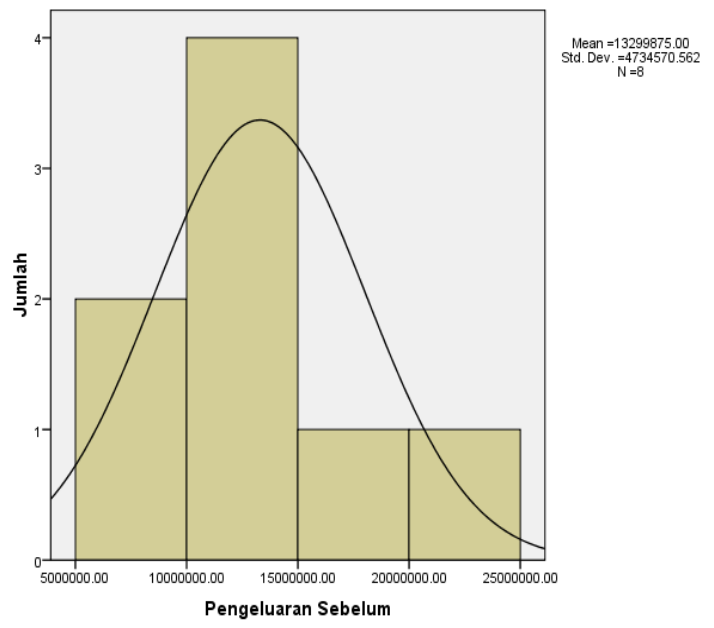

Gambar 12 Grafik jumlah pengeluaran sebelum menjadi gurandil di Desa Pangkal Jaya tahun 2015

Berdasarkan hasil penelitian sesudah bekerja sebagai gurandil biasa, pengeluaran tergolong kategori rendah apabila pengeluaran yang dikeluarkan lebih kecil dari Rp 56939066 per tahun, pengeluaran tergolong kategori sedang apabila mengeluarkan biaya antara Rp 56939 066 hingga lebih kecil dari Rp 90649684 dan tergolong tinggi apabila lebih besar dari Rp 90 649684.

Jenis pengeluaran yang dikeluarkan oleh gurandil baik gurandil cetek, gurandil biasa maupun gurandil tong adalah untuk membeli rokok karena kebiasaan orang atau masyarakat Desa Pangkal Jaya pada umumnya adalah merokok dan teah turun-temurum kepada anakanak. Hasil penelitian menunjukkan rata-rata responden mengeluarkan biaya untuk rokok adalah Rp 45000 per hari. Selain melihat tingkat pendapatan, pengeluaran, kesehatan, dan kondisi fisik rumah tingkat kesejahteraan juga dapat dilihat dari tingkat pendidikan yang diperoleh oleh rumah tangga khususnya rumh tangga 
gurandil. Berdasarkan hasil penelitian, tingkat pendidikan yang diperoleh paling tinggi oleh keluarga gurandil adalah Sekolah Menengah Atas (SMA). Akan tetapi masih banyak anakanak yang ada di Desa Pangkal Jaya mengalami putus sekolah ketika masih duduk di Sekolah Dasar (SD). Salah satu penyebabnya adalah motivasi dan minat anak-anak untuk sekolah dan menuntuk ilmu sangat minim dan juga tidak ada paksaan dari pihak lain untuk wajib menuntut ilmu.

\begin{abstract}
"ya neng, kalo untuk sekolah mah alhamdulillah bisa gratis sampai SMP, tapi anak-anak di sini ga punya kemauan neng buat sekolah, lebih suka main, lebih suka nyari duit. Kalo yang niat mah bisa diitung neng yang sampai SMA tapi alhamdulillah duit dari hasil gurandil bisa nyekolahkan anak sampai SMA dan untung anak saya ga mau seperti temen-temennya yang putus sekolah. Alhamdulillah anak saya mau sekolah. Mudah-mudahan sampai kuliah". (YY 2015)
\end{abstract}

Berdasarkan hasil penelitian, dapat disimpulkan bahwa tingkat kesejahteraan gurandil baik gurandil cetek, gurandil biasa, maupun gurandil tong mengalami peningkatan terlihat dari membaiknya kondisi fisik rumah dari sebelum menjadi sesudah gurandil, meningkatnya pendapatan dan pengeluaran sesuai dengan kebutuhan.

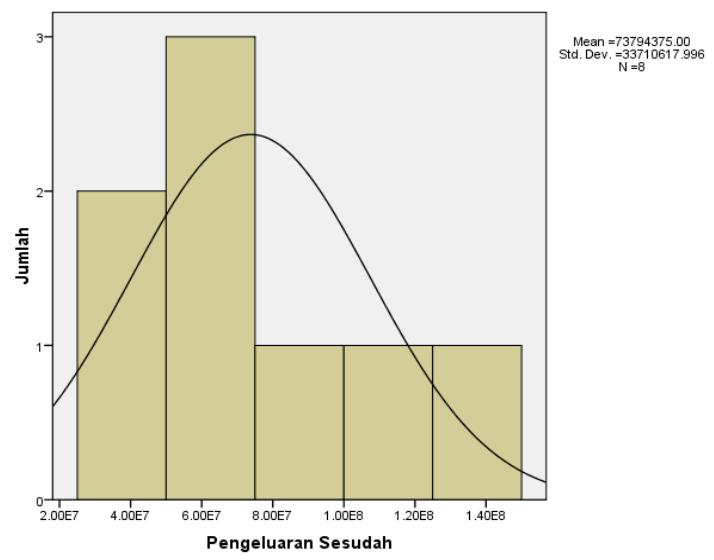

Gambar 13 Grafik jumlah pengeluaran sesudah menjadi gurandil di Desa Pangkal Jaya tahun 2015

\section{Hubungan Faktor Pendorong, Tingkat Aktivitas dan Kesejahteraan Rumah Tangga Gurandil}

\section{Hubungan Faktor Pendorong Munculnya Gurandil dan Tingkat Aktivitas Gurandil}

Faktor-faktor pendorong merupakan suatu faktor yang menyebabkan munculnya kegiatan penambangan tanpa izin atau gurandil. faktorfaktor tersebut yaitu faktor sosial, faktor hukum dan faktor ekonomi. Faktor pendorong yang dimaksud dalam penelitian ini adalah faktor yang melandasi munculnya kegiatan penambang gurandil bagi masyarakat Desa Pangkal Jaya maupun dari luar desa. Secara umum, faktorfaktor pendorong munculnya gurandil berhubungan dengan dengan tingkat aktivitas penambang gurandil untuk melakukan kegiatan penambangan tanpa izin. Uji hubungan yang dilakukan merupkan uji hubungan pada variabel aktivitas gurandil baik gurandil cetek, gurandil biasa, dan gurandil tong.

Peneliti menggunakan perangkat lunak SPSS melalui uji statistik non-parametrik melakukan uji Rank Spearman pada variabel faktor-faktor pendorong munculnya gurandil (X) dengan tingkat aktivitas gurandil dalam melakukan penambangan tanpa izin/tikus (Y). Data yang ada mengenai faktor-faktor pendorong munculnya gurandil ditotalkan dan dikelaskan dan diintervalkan menjadi tiga kelas yaitu rendah, sedang dan tinggi. Akhirnya diperoleh data rangking (ordinal). Kemudian data mengenai tingkat aktivitas gurandil yang dilihat dari lama bekerja, frekuensi bekerja, dan lain lain dikategorikan menjadi tiga kelas yaitu rendah, sedang dan tinggi. Hipotesis secara lebih lanjut dalam bab ini dijelaskan berdasarkan data kuantitatif yang didapatkan dengan menggunakan uji Kolerasi Rank Sperman ( $\alpha 5$ persen), didukung dengan penjelasan kualitatif deskriptif.

Tabel 8 Uji kolerasi Rank Sperman faktor faktor pendorong munculnya gurandil dan tingkat aktivitas gurandil (gurandil cetek, biasa, dan tong)

\begin{tabular}{llcc}
\hline & & $\begin{array}{c}\text { Faktor } \\
\text { Pendorong }\end{array}$ & $\begin{array}{c}\text { Aktivitas } \\
\text { Gurandil }\end{array}$ \\
\hline Faktor & Correlation & 1.000 & $.364^{*}$ \\
Pendorong & Coefficient & & \\
& Sig. (2-tailed) & .041 \\
& $\mathrm{~N}$ & 32 & 32 \\
Aktivitas & Correlation & $.364^{*}$ & 1.000 \\
Gurandil & Coefficient & & \\
& Sig. (2-tailed) & .041 &. \\
& $\mathrm{~N}$ & 32 & 32 \\
\hline
\end{tabular}

Berdasarkan uji korelasi, diperoleh nilai koefisien diperoleh sebesar 0.364 dengan signifikan 0.041. Berdasarkan data tersebut maka dapat dikatakan bahwa kedua variabel tersebut memiliki hubungan moderat. Maka H1 
diterima dan $\mathrm{H} 0$ ditolak. Uji stastistik terhadap kedua variabel tersebut disimpulkan bahwa terdapat hubungan antara variabel faktor pendorong munculnya gurandil dengan tingkat aktivitas gurandil melakukan penambangan emas tanpa izin.

\section{Hubungan Tingkat Aktivitas Gurandil dengan Tingkat Kesejahteraan Rumah Tangga Gurandil}

Aktivitas gurandil dalam melakukan penambangan merupakan suatu kegiatan utama yang dilakukan oleh penambang untuk mendapatkan nilai ekonomis/pendapatan. Tingkat aktivitas dilihat dari kategori gurandil yaitu gurandil cetek, gurandil biasa, dan gurandil tong. Tingkat kesejahteraan dibedakan menjadi tingkat kesejahteraan sebelum dan setelah responden menjadi gurandil. Tingkat aktivitas gurandil secara parsial sebelumnya tidak pernah dihubungkan secara terpisah dengan kondisi sosial ekonomi dalam hubungannya tingkat kesejahteraan. Peneliti kemudian memperjelas kasus ini menggunakan perangkat lunak SPSS melalui uji statistik nonparametik melakukan uji Rank Spearman pada variabel tingkat aktivitas gurandil (X) dengan tingkat kesejateraan (Y). Data yang ada mengenai aktivitas gurandil ditotalkan (gurandil cetek, gurandil biasa, gurandil tong) dan dikelaskan dan diintervalkan menjadi tiga kelas yaitu rendah, sedang dan tinggi. Akhirnya didapatkan data ranking (ordinal). Kemudian peneliti telah mengkode tingkat kesejahteraan berdasarkan tingkatan (ordinal).

Tabel 9 Uji korelasi Rank Spearman tingkat aktivitas gurandil dengan tingkat kesejahteraan rumah tangga sebelum menjadi gurandil di Desa Pangkal Jaya

\begin{tabular}{llrr}
\hline & & $\begin{array}{c}\text { Aktivitas } \\
\text { Gurandil }\end{array}$ & $\begin{array}{c}\text { Tingkat } \\
\text { Kesejahteraan } \\
\text { Sebelum }\end{array}$ \\
\hline Aktivitas & Correlation & 1.000 & .033 \\
Gurandil & Coefficient & & .857 \\
& Sig. (2-tailed) &. & 32 \\
& $\mathrm{~N}$ & .033 & 1.000 \\
Tingkat & Correlation & .857 &. \\
Kesejahteraan & Coefficient & 32 & 32 \\
Sebelum & Sig. (2-tailed) & & \\
& $\mathrm{N}$ & & \\
\hline
\end{tabular}

Berdasarkan uji korelasi Rank Spearman hubungan tingkat aktivitas gurandil dengan tingkat kesejahteraan rumah tangga sebelum bekerja sebagai gurandil diperoleh nilai koefisien sebesar 0.033 dengan signifikan 0.857. Berdasarkan data tersebut maka dapat dikatakan bahwa kedua variabel tersebut memiliki hubungan kurang berarti. Selain nilai korelasi yang diperoleh 0.033 juga diperoleh signifikansi 0.857 . Nilai signifikansi yang diperoleh memiliki nilai lebih besar dari nilai $\alpha$ yaitu 0.05 (5 persen) yang menginterpretasikan bahwa $\mathrm{H} 1$ diterima dan $\mathrm{HO}$ ditolak yang berarti bahwa terdapat hubungan antara tingkat aktivitas gurandil dalam melakukan penambangan emas tanpa izin dengan tingkat kesejahteraan sebelum menjadi gurandil.

Tabel 10 Uji korelasi Rank Spearman tingkat aktivitas gurandil dengan tingkat kesejahteraan rumah tangga sesudah menjadi gurandil di Desa Pangkal Jaya

\begin{tabular}{llrr}
\hline & & $\begin{array}{c}\text { Aktivitas } \\
\text { Gurandil }\end{array}$ & \multicolumn{2}{c}{$\begin{array}{c}\text { Tingkat } \\
\text { Kesejahteraan } \\
\text { Setelah }\end{array}$} \\
\hline $\begin{array}{l}\text { Aktivitas } \\
\text { Gurandil }\end{array}$ & $\begin{array}{l}\text { Correlation } \\
\text { Coefficient } \\
\end{array}$ & 1.000 & -.167 \\
& $\begin{array}{l}\text { Sig. (2- } \\
\text { tailed) }\end{array}$ &. & .362 \\
& $\mathrm{~N}$ & 32 & 32 \\
Tingkat & Correlation & -.167 & 1.000 \\
Kesejahteraan & Coefficient & & \\
Setelah & Sig. (2- & .362 & 32 \\
& tailed) & 32 &. \\
& $\mathrm{~N}$ & & \\
\hline
\end{tabular}

Uji korelasi Rank Spearman hubungan tingkat aktivitas dengan tingkat kesejahteraan rumah tangga setelah bekerja sebagai gurandil diperoleh nilai koefisien sebesar -0.167 dengan signifikan 0.362. Berdasarkan data tersebut maka dapat dikatakan bahwa kedua variabel tersebut memiliki memiliki hubungan lemah. Selain itu, signifikansi yang diperoleh nilai lebih besar dari nilai $\alpha$ yaitu 0.05 (5 persen) yaitu 0.362 yang menginterpretasikan bahwa $\mathrm{H} 1$ diterima dan $\mathrm{HO}$ ditolak yang berarti bahwa terdapat hubungan antara tingkat aktivitas gurandil dalam melakukan penambangan emas tanpa izin dengan tingkat kesejahteraan sesudah menjadi gurandil. Tanda negatif pada nilai kolerasi tingkat aktivitas gurandil menunjukkan bahwa terdapat hubungan yang berbanding 
terbalik. Artinya, ketika variabel (x) yaitu tingkat aktivitas gurandil tinggi maka disisi lain variabel (y) yaitu kesejahteraan rendah. Hal ini dikarenakan aktivitas yang dilakukan oleh gurandil baik gurandil cetek, dan gurandil biasa lebih banyak berkelompok dan menggunakan cara bagi hasil untuk bahan galian. Semakin berkelompok dalam melakukan penambangan maka semakin kecil hasil yang diperoleh maka akan berdampak pada kesejahetraan rumah tangga. Selain itu, berdasarkan pengamatan di lapang, tingginya aktivitas gurandil dapat meningkatkan kesejahteraan rumah tangga terlihat dari tingkat pendapatan yang meningkat, kondisi fisik tempat tinggal yang semakin bagus, dan lainnya.

\section{SIMPULAN DAN SARAN}

\section{Simpulan}

1. Mayoritas penduduk Desa Pangkal Jaya bermata pencaharian utama sebagai penambang gurandil dengan proporsi $85 \%$ dan $15 \%$ disektor lain seperti petani, pedagang, kuli bangunan, dan buruh tani.

2. Terdapat faktor penting yang mendorong munculnya gurandil yaitu faktor ekonomi, semakin rendahnya pendapatan untuk memenuhi kebutuhan menyebabkan masyarakat desa memilih bekerja sebagai gurandil. Selain itu, didorong karena lemahnya penegakan hukum dalam mengatasi permasalahan tentang pertambangan tanpa izin. Dengan bekerja sebagai penambang gurandil tidak memerlukan pendidikan yang tinggi.

3. Aktivitas penambang gurandil dikategorikan menjadi tiga yaitu berdasarkan gurandil cetek, guradil biasa dan gurandil tong. Tingkat aktivitas yang paling tinggi dilakukan oelh gurandil cetek karena memiliki frekusensi yang lebih banyak dalam melakukan penambangan ke Gunung Pongkor dibandingkan gurandil biasa dan gurandil tong.

4. Tingkat kesejahteraan rumah tangga gurandil paling tinggi terlihat pada gurandil tong. Hal ini dilihat dari tingkat pendapatan yang tinggi, kondisi fisik rumah yang semakin baik. Akan tetapi dari tingkat kesehatan, baik gurandil cetek, biasa maupun gurandil tong mengalami kondisi kesehatan yang menurun. Hal ini dikarenakan oleh aktivitas yang dilakukan untuk memenuhi kebutuhan keluarga.

5. Uji statistik Rank Spearman menunjukkan adanya hubungan antara faktor pendorong munculnya gurandil dengan tingkat aktivitas gurandil dalam melakukan penambangan emas tanpa izin. Dengan hasil koefisien yang diperoleh sebesar 0.364 dengan signifikan 0.041. Semakin banyak faktor pendorong munculnya gurandil maka semakin tinggi aktivitas gurandil dalam melakukan penambangan emas tanpa izin.

6. Uji statistik Rank Spearman antara variabel tingkat aktivitas gurandil dalam melakukan penambangan emas tanpa izin dengan tingkat kesejahteraan gurandil baik sebelum maupun sesudah gurandil diperoleh hasil bahwa terdapat hubungan antara kedua variabel tersebut. Dengan hasil koefisien masing-masing 0.033 dengan signifikan 0.857 dan -0.167 dengan signifikan 0.362 . Tanda negatif pada nilai kolerasi tingkat aktivitas gurandil menunjukkan bahwa terdapat hubungan yang berbanding terbalik.

\section{Saran}

1. Civitas akademika, penelitian ini perlu adanya pembandingan antar dua lokasi yang beragam sebagai pembanding antara aktivitas gurandil dan kesejahteraan rumah tangga gurandil yang tergolong homogen dan heterogen, sehingga dapat memperoleh hasil yang cukup baik melihat hubungannya.

2. Masyarakat dan gurandil, diharapkan dapat dijadikan pertimbangan dalam menentukan jenis pekerjaan yang sesuai dengan mempertimbangkan resiko dan keuntungan sehingga dapat kesejahteraan rumah tangga.

3. Perusahaan dan pemerintah diharapkan dapat menyusun arah kebijakan melandasi terciptakan penambangan gurandil (terkait faktor sosial, ekonomi maupun hukum), sehingga menciptakan kesejahteraan khususnya untuk rumah tangga. Serta perusahaan diharapkan lebih memperhatikan dan meningkatkan kepedulian kepada masyarakat sekitar lokal penambangan khususnya Desa Pangkal Jaya dengan memberdayakan dan meningkatkan ekonomi dan kesejahteraan masyarakat dengan cara mengembangkan potensi yang ada. 


\section{DAFTAR PUSTAKA}

[BPS] Badan Pusat Statistik. 2003. Indikator Kesejahteraan Rakyat 2003. Jakarta (ID): BPS

[BPS] Biro Pusat Statistik. 2005. Tingkat Kemiskinan di Indonesia. Berita resmi Statistik No. 47/IX/1 Septembr 2005. [Internet]. [diunduh 01 Oktober 2014]. Dapat diunduh dari: http://jakarta.Badan Pusat Statistik.go.id/fileupload/brs

Budimanta A. 2007. Kekuasaan dan Penguasaan Sumber Daya Alam : Studi Kasus Penambangan Timah di Bangka. Jakarta: Indonesia Center for Sustainable Development.

Erman E. 2010. Tambang, Perempuan dan Negara Gagal?. Samarinda. [Internet]. [Diunduh tanggal 19 Maret 2015 pukul 13.46]. Dapat diunduh dari: http://issuu.com/borneo2020/docs/erwizaerman-tambang_perempuan-dan-negara-gagal

Kristanto P. 2004. Ekologi Industri. Yogyakarta: ANDI

Ngadiran, Santoso P, Purwoko B. 2002. Dampak Sosial Budaya Penambangan Emas di Kecamatan Mandor Kabupaten Landa Propinsi Kalimantan Barat (Social Culture Impact of Gold Mining at Mandor in Landak Regency West Kalimantan Province). Sosiohumanika. [Internet]. [Diunduh tanggal 22 Maret 2015 pukul 22.25]. Edisi Januari 2002. 15 (1). 131

Paryono. 2005. Dampak Pencemaran Pertambangan Emas Tanpa Izin terhadap Ikan Baung di Sungai Cikaniki, Kawasan Pongkor, Bogor. [Tesis]. Bogor (ID): Institut Pertanian Bogor.

[Permen] Peraturan Menteri Energi dan Sumberdaya Mineral Republik Indonesia Nomor 24 Tahun 2012 Tentang Perubahan Atas Peraturan Menteri Energi Dan Sumber Daya Mineral Nomor 28 Tahun 2009 Tentang Penyelenggaraan Usaha Jasa Pertambangan Mineral dan Batubara.

Prayogo D. 2011. Socially Responsible Corporation: Peta Masalah, Tanggung Jawab sosial dan Pembangunan Komunitas pada Industri Tambang dan Migas di Indonesia. Jakarta (ID): Universitas Indonesia

Profil Desa Pangkal Jaya. 2013. Bogor (ID).

Risal et al. 2013. Analisis Dampak Kebijakan Pertambangan terhadap Kehidupan Sosial Ekonomi Masyarakat di Kelurahan Makroman. E-Journal Administrative Reform. [Internet]. Jurnal. [Diunduh tanggal 07 Oktober 2014]; 1(1): 117-131. Dapat diunduh dari: http://ar.mian.fisip-

unmul.ac.id/site/wpcontent/uploads/2013/06/Art ikel_ejournal_mulai_hlm_ganjil-ok\%20\%280603- $-\overline{13}-03-52-\overline{4} 5 \% 29 . \mathrm{pdf}$
Rusli S. 2005. Pengantar Ilmu Kependudukan. Jakarta (ID): LP3ES.

Saleg. 2007. Hukum Pertambangan di Indonesia. Jakarta: PT Raja Grafindo Persada.

Singarimbun M, Effendi S. 2006. Metode dan Proses Penelitian. Jakarta (ID): Pustaka LP3ES Indonesia

Siregar FF. 2009. Persepsi Masyarakat tentang Pembukaan Pertambangan Emas di Hutan Batang Toru (Studi Kasus Kecamatan Batang Toru, Kabupaten Tapanuli Selatan). [Skripsi]. Sumatera Utara (ID): Universitas Sumatera Utara.

Soemarwoto O. 2005. Ekologi Lingkungan Hidup dan Pembangunan. Jakarta: Djambatan.

Suharto E. 2005. Membangun Masyarakat Memberdayakan Rakyat (Kajian Strategis Pembangunan Kesejahteraan Sosial dan Pekerjaan Sosial). Bandung: PT Refika Aditama.

Sulton A. 2011. Dampak Aktivitas Pertambangan Bahan Galian Golongan C terhadap Kondisi Kehidupan Masyarakat Desa (Analisis SosioEkonomi dan Sosio-Ekologi Masyarakat Desa Cipinang, Kecamatan Rumpin, Kabupaten Bogor, Jawa Barat). [Skripsi]. Bogor (ID). Institut Pertanian Bogor

[UU] Undang-Undang Nomor 11 Tahun 2009 Tentang Kesejahteraan Sosial

[UU] Undang-Undang Nomor 11 tahun 1967 Tentang Ketentuan-ketentuan Pokok Pertambangan

Wibisono B. 2008. Model Kebijakan Pengelolaan Lingkungan Pertambangan Mineral yang Berkelanjutan (Studi Kasus: Pengelolaan Lingkungan Mod-ADA Di Kabupaten Mimika, Papua). [Disertasi]. Bogor (ID): Institut Pertanian Bogor.

Willybrodus, Chang W. 2012. Dampak Ekonomis Penambangan Emas bagi Masyarakat Mandor, Kalimantan Barat. [Jurnal Ilmiah Nasional]. [Internet]. [Diunduh pada tanggal 22 Maret 2015 pukul 22.28]. Edisi 38, No. 1/2012, ISSN 977-0125-9989-1-9 (LIPI, No. Akreditasi: 439/AU2/P2MI-LIPI/08/2012).

Zulqayyim. 2006. Dinamika Dua Kota Tambang: Perubahan Sosial dan Munculnya Tambang Rakyat di Sawahlunto Sumatera Barat dan Sungai Liat Bangka pada Masa Reformasi. [Artikel Penelitian]. Padang (ID): Fakultas Sastra, Universitas Andalas Padang. 